\title{
Fall and Winter Movements of Bowhead Whales (Balaena mysticetus) in the Chukchi Sea and Within a Potential Petroleum Development Area
}

\author{
LORI T. QUAKENBUSH, ${ }^{1,2}$ JOHN J. CITTA, ${ }^{1}$ JOHN C. GEORGE, ${ }^{3}$ ROBERT J. SMALL ${ }^{4}$ \\ and MADS PETER HEIDE-JØRGENSEN ${ }^{5}$
}

(Received 20 August 2009; accepted in revised form 9 November 2009)

\begin{abstract}
Working with subsistence whale hunters, we tagged 19 mostly immature bowhead whales (Balaena mysticetus) with satellite-linked transmitters between May 2006 and September 2008 and documented their movements in the Chukchi Sea from late August through December. From Point Barrow, Alaska, most whales moved west through the Chukchi Sea between $71^{\circ}$ and $74^{\circ} \mathrm{N}$ latitude; nine whales crossed in six to nine days. Three whales returned to Point Barrow for 13 to 33 days, two after traveling $300 \mathrm{~km}$ west and one after traveling $\sim 725 \mathrm{~km}$ west to Wrangel Island, Russia; two then crossed the Chukchi Sea again while the other was the only whale to travel south along the Alaskan side of the Chukchi Sea. Seven whales spent from one to 21 days near Wrangel Island before moving south to northern Chukotka. Whales spent an average of 59 days following the Chukotka coast southeastward. Kernel density analysis identified Point Barrow, Wrangel Island, and the northern coast of Chukotka as areas of greater use by bowhead whales that might be important for feeding. All whales traveled through a potential petroleum development area at least once. Most whales crossed the development area in less than a week; however, one whale remained there for 30 days.
\end{abstract}

Key words: bowhead whale, Balaena mysticetus, satellite telemetry, fall movements, Chukchi Sea, migration, habitat use, petroleum development, kernel density

RÉSUMÉ. De concert avec les pêcheurs de baleines de subsistance, nous avons apposé des transmetteurs satellitaires sur 19 baleines boréales (Balaena mysticetus) pour la plupart immatures entre les mois de mai 2006 et septembre 2008, puis nous avons tenu compte de leurs mouvements dans la mer de Tchoukotka de la fin août jusqu'au mois de décembre. À partir de Point Barrow, en Alaska, la plupart des baleines se déplaçaient vers l'ouest dans la mer de Tchoukotka entre $71^{\circ}$ et $74^{\circ} \mathrm{N}$ de latitude; neuf baleines ont fait la traversée en six à neuf jours. Trois baleines ont regagné Point Barrow pendant 13 à 33 jours, dont deux après avoir franchi 300 kilomètres en direction ouest et une après avoir franchi environ 725 kilomètres en direction ouest jusqu'à l'île Wrangel, en Russie; ensuite, deux baleines ont traversé la mer de Tchoukotka de nouveau tandis que l'autre était la seule baleine à se déplacer vers le sud le long du côté de la mer de Tchoukotka situé en Alaska. Sept baleines ont passé de un à 21 jours près de l'île Wrangel avant d'aller au sud du côté nord de Tchoukotka. Les baleines ont passé, en moyenne, 59 jours à suivre la côte de Tchoukotka vers le sud-est. L'analyse de la densité des noyaux a permis de déterminer que Point Barrow, l'île Wrangel et la côte nord de Tchoukotka sont des régions plus grandement utilisées par les baleines boréales, régions qui peuvent être importantes aux fins de l'alimentation. Toutes les baleines ont traversé une zone de mise en valeur éventuelle du pétrole au moins une fois. La plupart des baleines ont traversé la zone de mise en valeur en moins d'une semaine. Cela dit, une baleine est restée à cet endroit pendant 30 jours.

Mots clés : baleine boréale, Balaena mysticetus, télémétrie satellitaire, mouvements à l'automne, mer de Tchoukotka, migration, utilisation de l'habitat, mise en valeur du pétrole, densité des noyaux

Traduit pour la revue Arctic par Nicole Giguère.

\section{INTRODUCTION}

Bowhead whales (Balaena mysticetus) have been critical to the nutritional and cultural health of indigenous people of Alaska, Russia, and Canada for at least the last 2000 years
(Stoker and Krupnik, 1993), and they likely play a significant role as zooplankton grazers in Arctic seas (Brodie, 1980; Lowry and Frost, 1984; Lowry, 1993). Further, bowhead whales are potentially vulnerable to impacts of human activities such as the expansion of shipping and exploration

\footnotetext{
${ }^{1}$ Alaska Department of Fish and Game, 1300 College Road, Fairbanks, Alaska 99701, USA

${ }^{2}$ Corresponding author: Lori.Quakenbush@alaska.gov

${ }^{3}$ North Slope Borough, Department of Wildlife Management, PO Box 69, Barrow, Alaska 99723, USA

${ }^{4}$ Alaska Department of Fish and Game, 1255 West 8th Street, Juneau, Alaska 99811-5526, USA

${ }^{5}$ Greenland Institute of Natural Resources, c/o Greenland Representation, Strandgade 91, 3, Postboks 2151, DK-1016, Copenhagen, Denmark

(C) The Arctic Institute of North America
} 
and the extraction of petroleum resources. Thus, the Western Arctic stock of bowhead whales, also known as the Bering-Chukchi-Beaufort stock (Rugh et al., 2003), or the Bering Sea stock (Moore and Reeves, 1993), has been the focus of considerable research.

The general migration pattern of bowhead whales has been documented from aerial surveys (e.g., Brueggeman, 1982; Richardson et al., 1985; Ljungblad et al., 1986; Moore and Clarke, 1992; Treacy, 1992, 2002; Monnett and Treacy, 2005; Rugh et al., 2008), from shore- and ship-based observations (e.g., Carroll and Smithhisler, 1980; Rugh and Cubbage, 1980; Miller et al., 1986; Moore et al., 1995; Melnikov et al., 2004), from limited telemetry studies (Wartzok et al., 1990; Mate et al., 2000), and from the timing of indigenous whaling (Marquette, 1978; Durham, 1979; Stoker and Krupnik, 1993; Braham, 1995; Suydam and George, 2004; Noongwook et al., 2007). The Western Arctic stock winters in the Bering Sea (Brueggeman, 1982), and subsistence whalers regularly observe bowhead whales west of St. Lawrence Island from December to February (Noongwook et al., 2007).

In the spring (April and May), bowhead whales migrate north through the Chukchi Sea in the flaw lead formed when winds and currents separate the pack ice from the landfast ice (Braham et al., 1980; Ljungblad et al., 1986; George et al., 2004). Although this shear zone occurs near the Alaskan coast, its distance from shore is highly variable (LaBelle et al., 1983; Stringer and Groves, 1991).

Most bowhead whales are thought to summer in the eastern Beaufort Sea (Braham et al., 1980; Fraker and Bockstoce, 1980), before returning west between September and November along the Beaufort Sea coast to Point Barrow (Treacy, 2002). During aerial surveys conducted between 1979 and 1986, Ljungblad et al. (1987) began seeing bowhead whales in the northeastern Chukchi Sea in mid to late September. The whales' migration route once they pass Point Barrow and enter the Chukchi Sea is not well known, but the majority of whales are believed to move southwest towards the Chukotka Peninsula. During aerial surveys from late September to early November, most whales in the Chukchi Sea were observed on headings to the west southwest and were believed to cross the northern Chukchi Sea near Herald Shoal $\left(\sim 70^{\circ} \mathrm{N}\right)$. A few observations to the north near $72^{\circ} \mathrm{N}$ indicated that some whales traveled northwest from Point Barrow in light ice years, and some were thought to travel along the Alaskan side of the Chukchi Sea from Point Barrow to Icy Cape in heavy ice years (Moore, 2000; Moore et al., 2000). The whaling villages of Wainwright, Point Hope, and Kivalina do not hunt bowhead whales in the fall because few whales are accessible at that time, so the migration route beyond Icy Cape was unclear. Subsistence whalers have also observed more whales migrating near the western coast of Alaska in years with heavy sea ice (Huntington and Quakenbush, 2009a). Observations by Chukotka residents and research cruise reports indicate that bowhead whales move southeast along the northern Chukotka coast toward the Bering Strait from

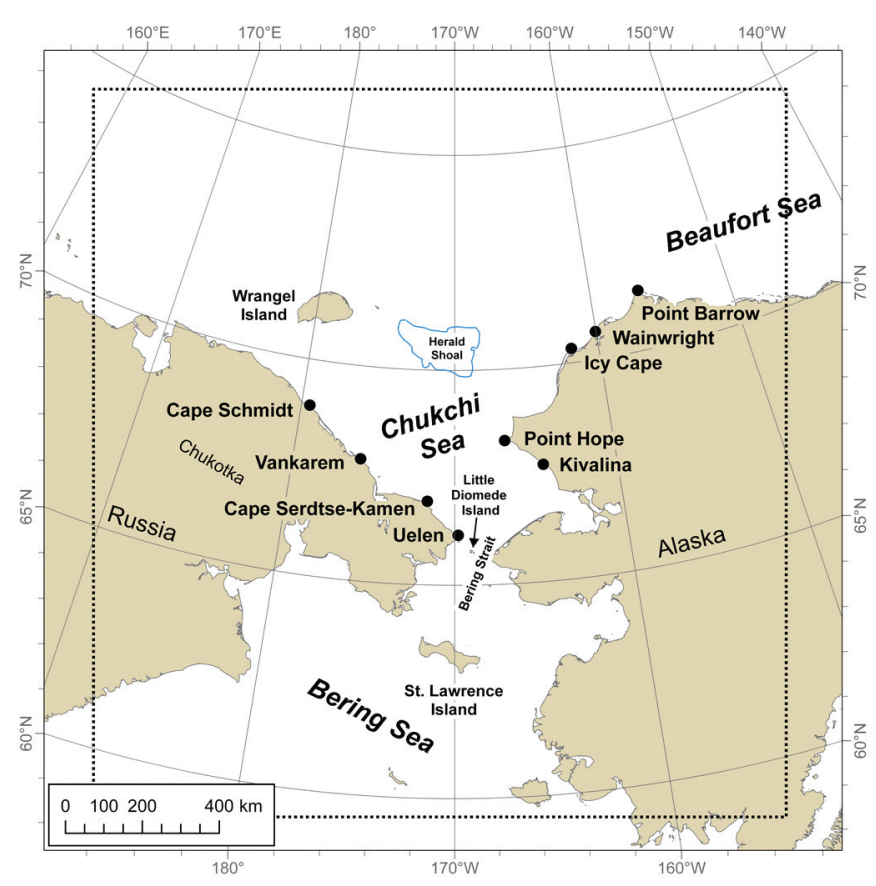

FIG. 1. Study area and outline for the grid of $5 \mathrm{~km}^{2}$ cells (dotted line) used for kernel density estimation.

late August through November (Bogoslovskaya et al., 1982; Miller et al., 1986; Melnikov and Bobkov, 1993; Melnikov et al., 1997). Large concentrations of whales have been observed near Vankarem (Fig. 1) in October during shipboard surveys (Johnson et al., 1981; Marquette et al., 1982; Miller et al., 1986; Moore et al., 1995). Passage through the Bering Strait begins in October and continues through early November (Moore and Reeves, 1993), and by December bowhead whales are again observed near St. Lawrence Island (Noongwook et al., 2007). Moore and Reeves (1993:337) provide a good summary (and map) of the general migration.

Far less is known about the distribution of wintering bowhead whales, but observations suggest that most bowheads overwinter along the edges of the pack ice and in polynyas in the western and central Bering Sea (Brueggeman, 1982). Residents of St. Lawrence Island see bowhead whales north of the island in years with little multiyear ice, and their Russian neighbors have reported seeing bowheads in polynyas along the southern coast of the Chukotka Peninsula in winter (Noongwook et al., 2007). Unpublished Russian literature also suggests that bowhead whales winter along the southern Chukotka Peninsula (Ainana et al., 1997).

The need for a better understanding of bowhead whale migration and movement patterns in the Chukchi Sea has increased substantially because of recent increases in human activities and decreases in sea ice. Specifically, in 2008, the U.S. Minerals Management Service (MMS) offered Lease Sale 193, which opened $\sim 120,000 \mathrm{~km}^{2}$ of the Chukchi Sea to activities associated with oil and gas development (U.S. Federal Register 73 January 2, 2008) (Fig. 2). Also, as sea ice decreases in extent and thickness, shipping will increase 


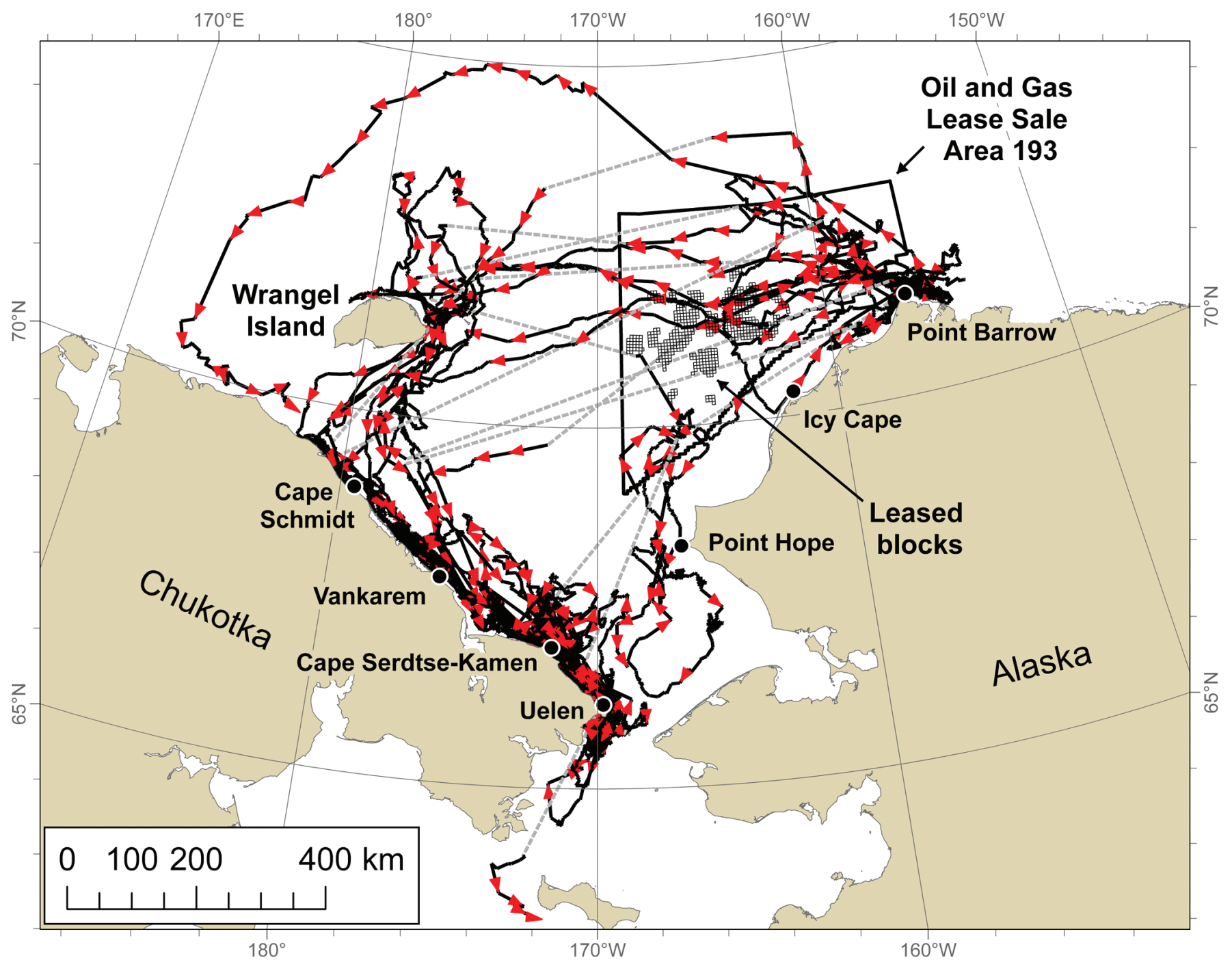

FIG. 2. Tracks of 15 satellite-tagged bowhead whales in the Chukchi Sea from August through December, 2006 through 2008, estimated from a filtered set of locations. Locations more than $200 \mathrm{~km}$ apart are connected with dashed lines.

within the Chukchi Sea to support exploration and extraction of petroleum resources and make use of new, ice-free shipping lanes (ACIA, 2004; Treadwell, 2008). Ships using the Northern Sea Route (along the northern Russian coast) and the Northwest Passage (along the northern Alaska coast and through the Canadian Archipelago) pass through the Bering Strait and the Chukchi Sea. There are concerns that 1) oil and gas activities and shipping may affect bowhead whale feeding and migration patterns, with possible negative effects on energetics, which could result in population level effects, and 2) altered migration patterns and declining populations of whales may affect the subsistence harvest and have a significant impact on Alaska Native culture. Whale migration and movement patterns likely are related to sea ice coverage, which has been decreasing in extent and thickness, making the effects of human activities more difficult to determine. Hence, understanding migration patterns of bowhead whales and the behavioral and ecological mechanisms that drive those patterns will be critical to assessing how bowhead whales may respond to reduced ice cover. This information will be needed in order to mitigate the impact of oil and gas activities and delineate safe shipping lanes.

Although the overall direction and timing of bowhead whale migrations in the Chukchi Sea are known, little is known at more specific spatial and temporal scales. Most of the information comes from subsistence whalers, whose knowledge is considerable but is specific to their nearshore whaling areas, and from aerial survey efforts in the Chukchi Sea, which have been limited compared to survey efforts in the Beaufort Sea (Miller et al., 1986). In particular, most bowhead whales are assumed to pass through the central Chukchi Sea (Moore and Reeves, 1993), but it is not known whether the main migration passes through the oil and gas exploration and development area (lease area) or if it does, how long whales remain in the lease area. Areas where bowhead whales congregate within the Chukchi Sea are also unknown, with the exception of the coastal area 
from Cape Schmidt to the Bering Strait along the north side of the Chukotka Peninsula (Miller et al., 1986; Moore et al., 1995). Our objective is to describe the movements of 19 satellite-tagged bowhead whales within the Chukchi Sea between September and December in 2006-08. We describe the location and timing of bowhead whale movements and identify areas where whales spend time, presumably feeding.

\section{METHODS}

\section{Study Area}

To allow for comprehensive analyses of bowhead whale movements within the Chukchi Sea, the study area covered all of the Chukchi Sea, including the western region of the Beaufort Sea (near Point Barrow, Alaska) and the northern region of the Bering Sea (Fig. 1).

Lease Sale 193 covers $\sim 120000 \mathrm{~km}^{2}$ of the Chukchi Sea and is located between $69^{\circ}$ and $73^{\circ} \mathrm{N}$ latitude and $156^{\circ}$ and $169^{\circ} \mathrm{W}$ longitude (U.S. Federal Register 73 January 2, 2008; Fig. 2). The lease area excludes a $25-80 \mathrm{~km}$ wide corridor along the Chukchi Sea coast of Alaska. Water depth within the majority of the lease area varies from $\sim 30$ to $80 \mathrm{~m}$; however, the northeastern corner of the lease area includes the Arctic Basin, which is more than $2900 \mathrm{~m}$ deep. The lease area is partitioned into 5354 blocks, most of which are 2304 ha in size. As of 2009, 487 of these blocks had been leased for petroleum exploration and extraction; more blocks may be leased in the future.

\section{Tagging}

We used the satellite-linked transmitter attachment and deployment system developed by the Greenland Institute of Natural Resources (Heide-Jørgensen et al., 2001, 2003) to deploy tags on bowhead whales, and the Argos system of satellites to obtain data from the tags. We used two types of tags: the SPOT tag, from which only estimated locations of whales are obtained, and the SPLASH tag, from which both estimated locations and dive behavior are obtained; both types of tags were manufactured by Wildlife Computers (Redmond, Washington, USA).

Each SPOT transmitter was housed inside a stainless steel cylinder (20 mm diameter) that was attached to a stainless steel anchor shaft $(24.5 \mathrm{~cm}$ long) with a cutting head and flexible barbs (5 $\mathrm{cm}$ long) along the shaft to impede expulsion from the blubber. The anchor shaft and cylinder were implanted beneath the whale's skin $\sim 21 \mathrm{~cm}$ into the blubber, leaving $\sim 3.5 \mathrm{~cm}$ of the cylinder outside of the skin, with a short $(15 \mathrm{~cm})$ antenna extending from the top. The transmitter, housing, and anchor shaft weighed $240 \mathrm{~g}$.

The SPLASH transmitter $(8.5 \times 5 \times 2.5 \mathrm{~cm})$ was deployed on the surface of the whale's skin using a stainless steel anchor shaft, with a cutting head and flexible barbs $(4 \mathrm{~cm}$ long) along its length, which was implanted beneath the whale's skin. The total length of the transmitter and anchor shaft was $23.5 \mathrm{~cm}$, of which $21 \mathrm{~cm}$ went into the blubber and $2.5 \mathrm{~cm}$ remained above the skin. A short $(16 \mathrm{~cm})$ antenna extended from the top of the transmitter. The transmitter and anchor together weighed 294 g. In 2008, we used a modified shaft on all SPLASH tags. The new shaft had the same cutting head and barbs, but the transmitter was mounted to a steel plate that swiveled on the shaft, allowing the transmitter to move to the position of least hydrodynamic resistance. This transmitter and anchor weighed $300 \mathrm{~g}$.

We attached the SPOT tags to whales using a $2 \mathrm{~m}$ or $4 \mathrm{~m}$ long fiberglass pole system, used as a jab-stick (HeideJørgensen et al., 2003), or an air gun (ARTS, Air Rocket Transmitter System, see Heide-Jørgensen et al., 2001). The pole system included a biopsy tip (manufactured by CETADART, Denmark), a hollow stainless steel cylinder $2.5 \mathrm{~cm}$ long and $0.6 \mathrm{~cm}$ in diameter with internal barbs, which was designed to obtain a skin biopsy during tag deployment that could be analyzed to determine the gender of tagged whales. When we used the ARTS, the SPOT tag was placed into a plastic cylindrical projectile that was loaded into the aluminum barrel of the air gun and propelled toward the whale using compressed air from a SCUBA tank (HeideJørgensen et al., 2001). Penetration depth was controlled by a stopper on the plastic projectile when using the air gun and by a plastic device that holds the transmitter onto the pole when using the pole system. SPLASH tags do not fit into the barrel of the ARTS and were deployed only by using the fiberglass pole system (Heide-Jørgensen et al., 2003).

In the fall, we deployed tags from aluminum boats $(\sim 5.5-$ $6.1 \mathrm{~m}$ long) with outboard motors, whereas in spring, we stood on the nearshore ice edge near Barrow and deployed transmitters as bowhead whales passed by.

\section{Location Processing}

Transmitter locations are estimated from the number of times the transmitter communicates with Argos satellites when the whale is at the surface. The location error is estimated by the Argos system and characterized by "location classes" (see Argos, 2008 for a complete description). Location classes are only an approximate representation of location accuracy (e.g., Vincent et al., 2002). Instead of using only the locations representing the highest accuracy ( 2 or 3 ), we chose to use all available location classes (B, A, 0, 1, 2, 3) and a filter developed by Freitas et al. (2008) in R version 2.5.1 (available online from R-project.org) to remove the less accurate locations. The filter has separate velocity and angular components.

Bowhead whale locations that resulted in swim velocities greater than $1.94 \mathrm{~m} / \mathrm{s}$ were removed unless they were within $5 \mathrm{~km}$ of the previous location. The threshold velocity of $1.94 \mathrm{~m} / \mathrm{s}$ was based on direct measurements during spring migration and a literature review, which indicated that this velocity is the maximum observed migration speed of bowheads not fleeing vessels or assisted by currents (Zeh 
et al., 1993). The angular component of the filter is used to remove locations with a high degree of location error that fall far from the line of travel, but still within the threshold velocity. These locations are essentially outliers, and they create "spikes" or acute deviations in the line of travel (e.g., Keating, 1994; Freitas et al., 2008). For location $i$, this deviation is measured as the angle between locations $i-1, i$, and $i+1$. We used the default settings within the Freitas et al. (2008) filter; i.e., within $2.5 \mathrm{~km}$ of the track line, locations resulting in angles below $15^{\circ}$ were removed and locations between 2.5 and $5 \mathrm{~km}$ from the track line were removed if they resulted in angles under $25^{\circ}$ (see the manual for Package "argosfilter" for more detail, available online at cran. r-project.org). We then removed locations that fell on land to establish the final set of locations used to determine bowhead whale migratory paths and areas of concentrated use.

\section{Migration Paths}

To determine where tagged whales crossed the Chukchi Sea, we plotted whale locations in ArcGIS and used Hawth's Analysis Tools for ArcGIS developed by H. Beyer to combine locations into tracks. (Hawth's Analysis Tools have now been incorporated into "Geospatial Modelling Environment," which is available at http://www.spatialecology.com/gme/.) To distinguish segments of the track that were well known (many locations) from those that were less known (few locations), we arbitrarily chose to represent segments with less than $200 \mathrm{~km}$ between locations by a solid line and segments with more than $200 \mathrm{~km}$ between locations with a dashed line (Fig. 2). We also report the average minimum number of days required to cross the Chukchi Sea and to enter the Bering Sea. Because not all whales migrate close to the Russian shoreline, we defined whales as having crossed the Chukchi Sea when they came within $100 \mathrm{~km}$ of the Chukotka Peninsula or Wrangel Island.

\section{Areas of Concentrated Use (Kernel Density Estimation)}

We used kernel densities to identify geographic areas associated with a high probability of use by bowhead whales (e.g., Silverman, 1986; Worton, 1989; Wand and Jones, 1995). Kernel density estimation is a non-parametric method for calculating the probability that an animal occurs within a defined area. Such probability distributions are also known as utilization distributions (e.g., Kernohan et al., 2002); however, we use the term "kernel density" because it describes the method used to generate the probability distribution of animal locations.

When calculating a kernel density, we overlaid each whale location with a two-dimensional probability density function, known as a kernel function. For example, a "normal" kernel is based on a normal probability density function, which describes the shape of the kernel using a mean and a variance. For each dimension, the mean of the kernel is equal to the point location in that dimension (i.e., the latitude or longitude). However, because each kernel corresponds to a single location, the variance of the kernel cannot be calculated using standard formulas for variance. Therefore, the variance of the kernel, also known as the bandwidth, must be estimated by other means (see Bandwidth Selection below). The total probability density for any location within the study area is calculated by summing the individual kernels and scaling in such a way that the final kernel density, which includes the probability for all locations, integrates to 1 . Kernel densities are often described using percent probability contours, which are the contours that contain the desired percentage of total probability within the smallest area. For example, the $10 \%$ probability contour contains $10 \%$ of the probability of use within the smallest area on the surface of the kernel density. This results in an inverse relationship between the probability of finding a whale location and the value of the contour; i.e., a $10 \%$ probability contour contains only areas with a high probability of use, while a $90 \%$ probability contour contains areas with both high and low probabilities of use. If we visualized the final kernel density in three dimensions, where the height of the surface represents probability of use, it would be wider at the bottom and come to a peak at the top. The $10 \%$ probability contour would surround the peak, whereas the $90 \%$ probability contour would be located lower down.

When calculating kernel densities in practice, a study area is usually divided into grid cells within which individual kernels are summed. We overlaid the study area with a grid of $5 \mathrm{~km}^{2}$ cells that was large enough (135682 cells) to contain the complete kernel density for all whales (Fig. 1). The grid had a modified Albers projection that was shifted north and west of the standard Alaska Albers projection; our projection had a central meridian of $170^{\circ} \mathrm{W}$ and standard parallels of $65^{\circ}$ and $75^{\circ} \mathrm{N}$ latitude.

The number of locations per whale varied from day to day. To standardize the contributions of individual whales within days, we split the day into four 6-hour periods and selected the location with the highest location class within each time period. When multiple locations within a time period had the same location class, we selected the location that was transmitted the earliest, thereby spacing the locations over time. We then generated a kernel density for each whale in each of the four months of our analysis, September-December. To remove density that occurred on land, the kernel density was multiplied by a density that had cells coded 0 for land and 1 for water. We then rescaled the density for each whale so that it integrated to 1 .

Tags provided differing amounts of information regarding migration paths and areas of concentrated use because their longevity and performance varied. We did not want tags that contributed little information to have equal weight in the kernel densities, and therefore we weighted the contribution of individual whales according to the number of locations used to compute the kernel density for each whale within each month. Specifically, on a monthly basis the kernel density within each grid cell was multiplied by the proportion of data contributed by that whale. The cell densities 
TABLE 1. Characteristics and satellite tag information for 19 bowhead whales used for kernel density analyses, including 15 whales used to estimate tracks across the Chukchi Sea and Oil and Gas Lease Area 193.

\begin{tabular}{|c|c|c|c|c|c|c|}
\hline Whale ID & Tagging Date & Tagging Location & Length (m) & Sex & Tag Duration w/in Chukchi (d) & Used for Track Maps? \\
\hline B06-0 $01^{1}$ & 12 May 06 & Barrow & 13.7 & $\mathrm{M}$ & 30 & Yes \\
\hline B06- $03^{1}$ & 21 September 06 & Barrow & 10.6 & ? & 23 & No \\
\hline B $07-02^{2}$ & 29 August 07 & Barrow & 13.7 & $\dot{\mathrm{F}}$ & 4 & No \\
\hline B07-03² & 29 August 07 & Barrow & 11.5 & $\mathrm{~F}$ & 2 & No \\
\hline B $07-04^{2}$ & 29 August 07 & Barrow & 11.0 & ? & 16 & Yes \\
\hline B $08-01^{2}$ & 12 August 08 & Canada & 10.7 & $\dot{\mathrm{F}}$ & 125 & Yes \\
\hline B $08-02^{2}$ & 09 September 08 & Barrow & 12.2 & M & 37 & Yes \\
\hline B $08-03^{2}$ & 10 September 08 & Barrow & 14.5 & ? & 73 & Yes \\
\hline B08-04 & 19 September 08 & Barrow & 11.9 & ? & 1 & No \\
\hline B08-0 $5^{1}$ & 20 September 08 & Barrow & 10.7 & F & 3 & Yes \\
\hline B $08-06^{2}$ & 20 September 08 & Barrow & 10.0 & ? & 102 & Yes \\
\hline $\mathrm{B} 08-07^{2}$ & 20 September 08 & Barrow & 10.0 & $\dot{\mathrm{M}}$ & 101 & Yes \\
\hline $\mathrm{B} 08-08^{2}$ & 23 September 08 & Barrow & 10.0 & $?$ & 99 & Yes \\
\hline B08-09 & 23 September 08 & Barrow & 9.1 & M & 76 & Yes \\
\hline B08-10 1 & 23 September 08 & Barrow & 10.0 & M & 99 & Yes \\
\hline B08-11 $1^{1}$ & 23 September 08 & Barrow & 10.0 & M & 99 & Yes \\
\hline B08-12 1 & 23 September 08 & Barrow & 10.0 & M & 99 & Yes \\
\hline B $08-13^{2}$ & 23 September 08 & Barrow & 10.0 & $?$ & 97 & Yes \\
\hline B08-14² & 23 September 08 & Barrow & 13.7 & M & 99 & Yes \\
\hline
\end{tabular}

${ }^{1}$ SPOT $=$ Tag that provides locations only.

${ }^{2} \mathrm{SPLASH}=$ Tag that provides locations and dive data.

for each whale were then summed to generate a single kernel density for all whales within each month.

\section{Bandwidth Selection}

Kernel densities are known to be insensitive to the selection of the kernel function, but highly sensitive to the selection of bandwidth (Silverman, 1986). For wildlife studies, least squares cross-validation (LSCV) is the most common method of bandwidth selection (e.g., Seaman and Powell, 1996; Seaman et al., 1999; Gitzen and Millspaugh, 2003). Based upon simulation studies, LSCV is known to be unbiased, but highly variable (Park and Marron, 1990). In other words, multiple realizations of the same kernel density may vary greatly. To overcome this problem, a number of alternative methods have been developed for specifying the bandwidth matrix, such as "biased least squares cross validation" and "plug-in" estimators (e.g., Wand and Jones, 1995). We used Smoothed Cross-Validation (SCV) as described by Duong and Hazelton (2005). Assume $\mathrm{X}$ is a matrix of locations (e.g., latitude and longitude), $\mathrm{H}$ is a matrix of bandwidths, and $\mathrm{G}$ is a pilot bandwidth matrix. Assuming a normal (i.e., Gaussian) kernel with a zero mean vector and identity covariance matrix $(\varphi)$, then:

$S C V(H)=n^{-1}(4 \pi)^{-d / 2}|H|^{-1 / 2}+n^{-2} \sum_{i=1}^{n} \sum_{j=1}^{n}\left(\phi_{2 H+2 G}-2 \phi_{H+2 G}\right)\left(X_{i}-X_{j}\right)$

The SCV selector of $\mathrm{H}_{\mathrm{SCV}}$ is the minimizer of $\mathrm{SCV}(\mathrm{H})$. The pilot bandwidth matrix, $\mathrm{G}$, is selected by minimizing the Asymptotic Integrated Mean Squared Error (AIMSE), which is the difference between the density of locations and the density estimated with bandwidth matrix $\mathrm{H}$. A closedform solution for $\mathrm{G}$ is provided in Duong and Hazelton
(2005). To ease computation, the pilot bandwidth matrix contains only the diagonal components of the bandwidth. Therefore, pre-scaling or pre-sphering of the data is recommended (Duong and Hazelton, 2005).

When there are no replications of locations and the pilot bandwidth matrix $(\mathrm{G})$ is equal to zero, SCV converges on LSCV. In effect, the pilot bandwidth matrix pre-smoothes the data to generate a less variable (and more reliable) bandwidth. Asymptotic analyses and simulation studies have shown that SCV is unbiased like LSCV, but is also less variable than LSCV for a variety of density shapes (Duong and Hazelton, 2005). A bandwidth with less variability is desirable for our study, as this means the bandwidth will be less sensitive to how locations are sampled. We calculated $\mathrm{H}_{\mathrm{SCV}}$ using package 'ks' (Duong, 2007) in R version 2.5.1 (available online from R-project.org). As recommended by Duong and Hazelton (2005), we pre-scaled our data before calculating bandwidth matrices.

\section{Assumptions of Kernel Densities}

Kernel density estimators are non-parametric and therefore make no assumptions about the statistical distribution of bowhead whale locations. However, using kernel densities to infer the importance of geographic areas for bowhead whales must be done with caution. We implicitly assume that our sample of whale locations reflects the true distribution of whales, both tagged and untagged. However, the movements of tagged whales may not represent those of untagged whales, and the probability of receiving a transmission may depend upon whale behavior. For example, if whales spend less time at the surface while migrating, migration corridors may be underrepresented within the sample of locations. Even if our sample of whale locations 


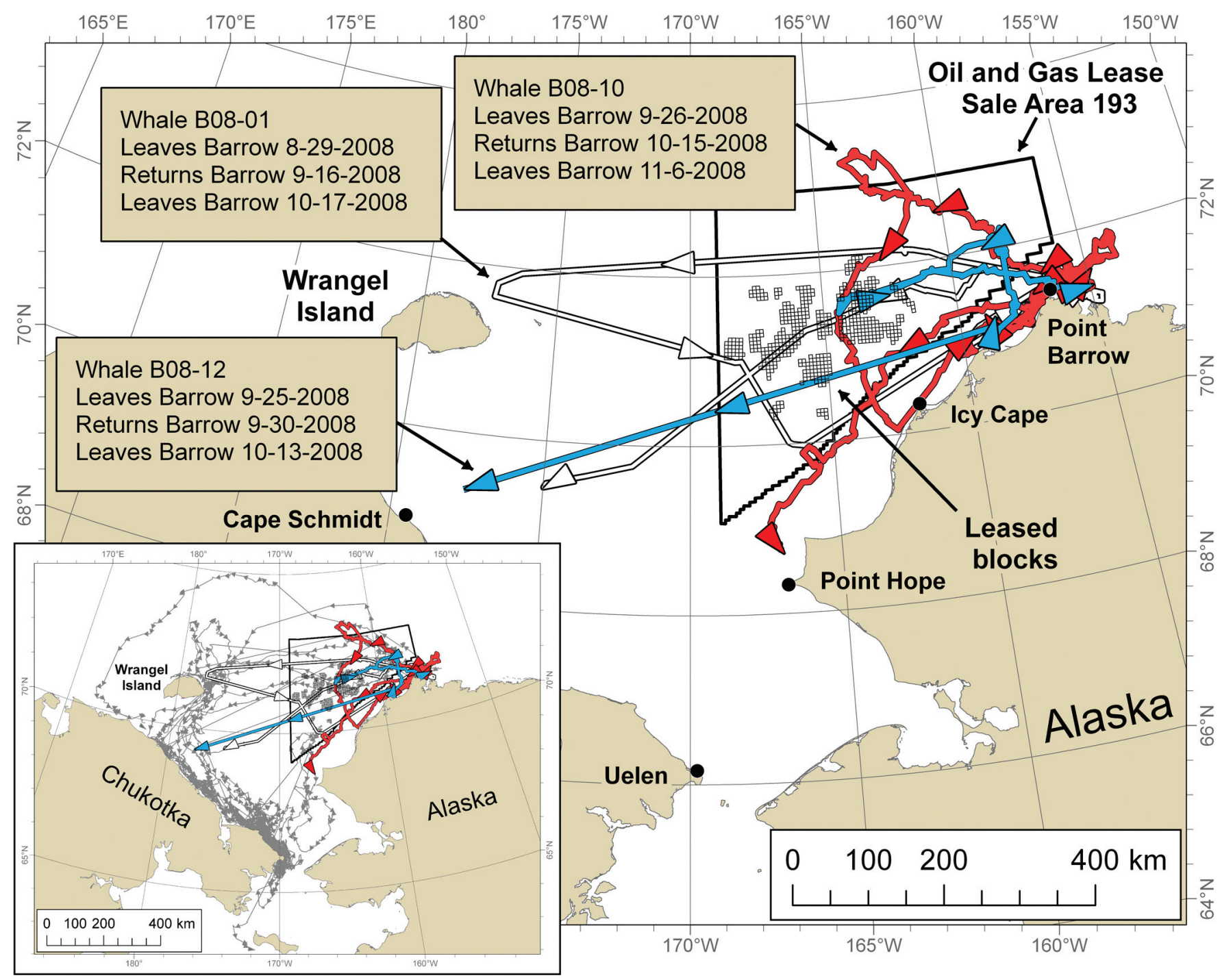

FIG. 3. Tracks of the three satellite-tagged bowhead whales that returned to the Barrow area after moving west into the Chukchi Sea in 2008. Inset shows all tracks from Figure 2 (dashed lines) with the tracks that returned to Barrow (bold solid lines) for comparison.

is representative of the population, probability of use may not accurately reflect the importance of a geographic area. Geographic areas with a low probability of use might still be important. For example, if whales spend little time in migratory corridors, the probability of use will be low within those corridors, but they remain important.

\section{RESULTS}

\section{Migration Paths}

Locations from 15 of the 19 bowhead whales tagged between spring 2006 and fall 2008 were analyzed to determine their general movements through the Chukchi Sea; locations from the remaining four whales were too sparse to determine migratory paths (Table 1 ). Most whales moved west through the Chukchi Sea between the latitudes of $71^{\circ}$ and $74^{\circ} \mathrm{N}$ (Fig. 2). Seven whales traveled to Wrangel Island before moving south to the coast of northern Chukotka and then followed that coast southeastward. The one whale that crossed farthest to the north was the only one to go west of Wrangel Island $(\sim 240 \mathrm{~km})$ before heading south to the Chukotka coast.

Three whales crossed the Chukchi Sea and then returned east to Point Barrow, two after traveling $\sim 270 \mathrm{~km}$ west and one after traveling $\sim 725 \mathrm{~km}$ to Wrangel Island (Fig. 3). Specifically, whale B08-10 left Point Barrow for 20 days, first moving $\sim 330 \mathrm{~km}$ northwest and then south $\sim 360 \mathrm{~km}$ to the Alaska coast near Icy Cape, then back up the coast to Point Barrow, where it stayed for 23 days before traveling southwest along the Alaska coast; this was the only whale that did not cross the Chukchi Sea to Chukotka during migration (Fig. 3). Whale B08-01 left Point Barrow for 19 days, moving west $\sim 725 \mathrm{~km}$ to within $\sim 30 \mathrm{~km}$ of the east coast of Wrangel Island before returning east to Point Barrow for 32 days, and then crossed the Chukchi Sea for a second time towards Cape Schmidt on the Chukotka Peninsula. Whale 
TABLE 2. Timing and duration of locations from satellite-tagged bowhead whales within Oil and Gas Lease Sale Area 193 in the Chukchi Sea.

\begin{tabular}{|c|c|c|c|c|}
\hline Whale ID & \# Locations ${ }^{1}$ & Starting Day & Ending Day & Duration $(d)^{2}$ \\
\hline B06-01 & 76 & 15 October 06 & 19 October 06 & 5 \\
\hline В07-04 & 8 & 31 August 07 & 02 September 07 & 3 \\
\hline \multirow[t]{3}{*}{ B $08-01$} & 9 & 31 August 08 & 31 August 08 & 1 \\
\hline & 5 & 10 September 08 & 12 September 08 & 3 \\
\hline & 14 & 18 October 08 & 25 October 08 & 8 \\
\hline B08-02 & 44 & 13 September 08 & 19 September 08 & 7 \\
\hline B08-03 & 55 & 11 September 08 & 15 September 08 & 5 \\
\hline B08- $05^{3}$ & 7 & 23 September 08 & 23 September 08 & 1 \\
\hline B08-06 & 10 & 25 September 08 & 29 September 08 & 5 \\
\hline B08-07 & 79 & 26 September 08 & 25 October 08 & 30 \\
\hline B08-08 & 55 & 26 September 08 & 29 September 08 & 4 \\
\hline В08-09 & 44 & 26 September 08 & 29 September 08 & 4 \\
\hline \multirow[t]{6}{*}{ B $08-10^{4}$} & 113 & 26 September 08 & 01 October 08 & 6 \\
\hline & 66 & 03 October 08 & 05 October 08 & 3 \\
\hline & 17 & 07 November 08 & 08 November 08 & 2 \\
\hline & 1 & 09 November 08 & 09 November 08 & 1 \\
\hline & 10 & 12 November 08 & 14 November 08 & 3 \\
\hline & 94 & 15 December 08 & 25 December 08 & 11 \\
\hline B08-11 & 24 & 26 September 08 & 27 September 08 & 2 \\
\hline \multirow[t]{2}{*}{ B08-12 } & 137 & 25 September 08 & 25 October 08 & 31 \\
\hline & 5 & 18 December 08 & 20 December 08 & 3 \\
\hline B08-135 & 19 & 26 September 08 & 28 September 08 & 3 \\
\hline
\end{tabular}

${ }^{1}$ The sets of locations for distinct periods when individual whales were located in the lease area are listed in separate rows.

${ }^{2}$ Durations were calculated as the number of days between the first and last recorded locations within the lease area; because locations were not necessarily received daily, durations are minimums.

${ }^{3}$ This tag stopped transmitting within one day of entering the lease area.

${ }^{4}$ This whale did not travel across the Chukchi Sea to Chukotka, but rather traveled south along the Alaska coast; see Fig. 3.

${ }^{5}$ This tag stopped transmitting within the lease area and began transmitting again on 10 October 2008 off the coast of Chukotka.

B08-12 left Point Barrow for six days, moving $\sim 275 \mathrm{~km}$ west and then returned to Point Barrow for 13 days before crossing the Chukchi Sea, also towards Cape Schmidt on the Chukotka Peninsula (Fig. 3).

Twelve whales had enough locations to determine how quickly they crossed the Chukchi Sea and came within $100 \mathrm{~km}$ of the Chukotka Peninsula or Wrangel Island. Nine whales crossed without pausing, arriving on average within 7.1 days after leaving Point Barrow (range $=6-9$ days). These whales left Point Barrow between 29 August and 14 October (average $=18$ September) and came within $100 \mathrm{~km}$ of Chukotka or Wrangel Island between 9 September and 31 October (average $=25$ September).

Three whales did not follow this pattern. B08-07 paused for five days over the shelf break $\sim 120 \mathrm{~km}$ northwest of Point Barrow (Fig. 1) and required 14 days to cross the Chukchi Sea (25 September to 9 October). B08-01 crossed the Chukchi Sea twice: the first crossing lasted seven days, while the second, longer crossing angled southwest across the Chukchi Sea (Fig. 3), requiring 14 days. B08-10 migrated down
TABLE 3. The number of bowhead whale locations for each whale that were used to estimate monthly kernel densities for September through December, 2006-08. The year when locations were recorded is indicated by the Whale ID (i.e., B06-01 represents the first whale in 2006). Twenty locations were collected between 29 and 31 August; for analysis, these locations were pooled with those collected in September.

\begin{tabular}{lcccccc}
\hline \hline & \multicolumn{5}{c}{ Month } & \\
\cline { 2 - 5 } Whale ID & August & September & October & November December & Total \\
\hline B06-01 & & & 55 & 31 & 86 \\
B06-03 & & & & 3 & 3 \\
B07-02 & 5 & 11 & & & 5 & 16 \\
B07-03 & 5 & & & & & 5 \\
B07-04 & 5 & 47 & & & & 51 \\
B08-01 & 5 & 49 & 68 & 54 & 61 & 237 \\
B08-02 & & 66 & 64 & & & 130 \\
B08-03 & & 76 & 120 & 69 & & 265 \\
B08-04 & & 3 & & & & 3 \\
B08-05 & & 7 & & & & 7 \\
B08-06 & & 22 & 108 & 79 & 110 & 319 \\
B08-07 & & 36 & 92 & 66 & 94 & 288 \\
B08-08 & & 23 & 88 & 86 & 101 & 298 \\
B08-09 & & 23 & 56 & 35 & 11 & 125 \\
B08-10 & & 27 & 121 & 110 & 87 & 345 \\
B08-11 & & 20 & 114 & 104 & 102 & 340 \\
B08-12 & & 22 & 25 & 25 & 11 & 83 \\
B08-13 & & 14 & 54 & 58 & 71 & 197 \\
B08-14 & & 7 & & 43 & 83 & 133 \\
Total & 20 & 453 & 965 & 763 & 731 & 2932 \\
\hline \hline
\end{tabular}

the Alaskan coast and did not come within $100 \mathrm{~km}$ of the Chukotka Peninsula until 29 November, 64 days after leaving Point Barrow.

Most whales that crossed the Chukchi Sea remained along the coast of Chukotka until entering the Bering Sea. Whales spent an average of 59 days along the coast of Chukotka before entering the Bering Sea (range $=23-90$ days). The average date of entering the Bering Sea was 5 December, but the entry dates ranged from 6 November to 1 January. On 8 December 2008, the first tagged whale (B08-09) reached St. Lawrence Island $\sim 8$ days after leaving the Chukchi Sea.

\section{Use of Lease Sale Area and Leased Blocks}

Fourteen of the 19 tagged whales transmitted positions that were located within the lease area, indicating they crossed some portion of it (Table 2, Fig. 2). The five whales that did not transmit within the lease area also did not transmit from north or south of the lease area. Hence, there is no evidence these whales migrated around the lease area. Locations within the lease area were recorded near both the eastern and western boundaries for eight of the whales that crossed it, providing a minimum estimate of the time needed for the crossing. Most of these eight whales crossed the lease area in less than one a week (median $=5$ days); however, one whale (B08-07) lingered within the lease area for 30 days before leaving, skewing the average duration to 7.6 days. Of the 14 whales that transmitted from within the lease area, three spent long periods there (B08-12: 34 days; 


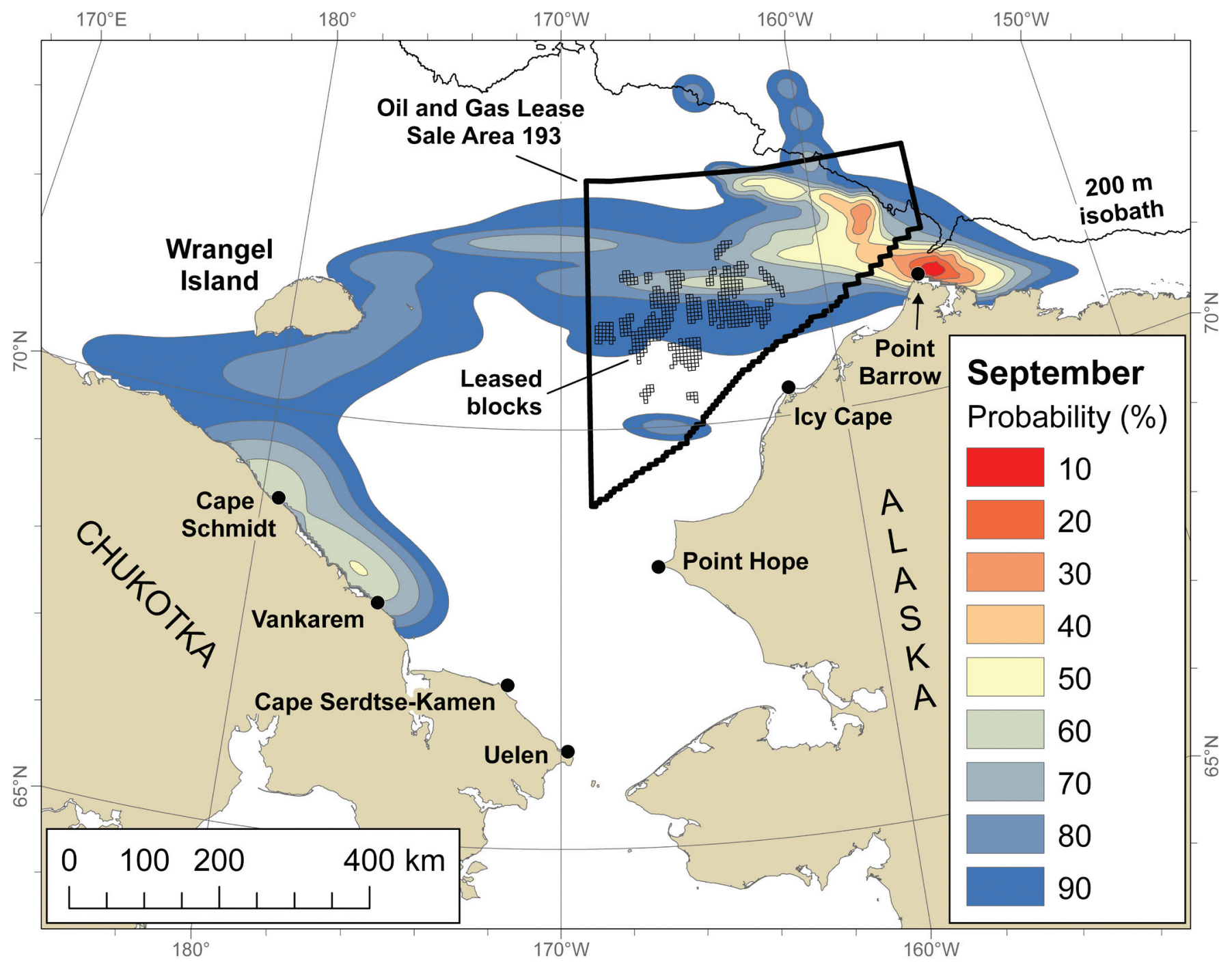

FIG. 4. Contours showing the probability of use (\%) by bowhead whales in September, 2006-08.

B08-07: 30 days; and B08-10: 26 days; Table 2). Time spent in the lease area by the other 11 whales ranged from 1 to 12 days (Table 2).

Of the 14 whales that crossed some portion of the lease area, all but one then traveled farther west to Wrangel Island or Chukotka. The exception was whale B08-10, which first passed across the northern boundary of the lease area and then turned and traversed the lease area from north to south before returning to Point Barrow (Table 2, Fig. 3). After leaving Point Barrow on 6 November, this whale then migrated down the coast of Alaska, moving back and forth across the southwest border of the lease area six times between September and December (Table 2, Fig. 3). Some whales did not provide enough locations to determine how they traversed the lease area; however, it is known that they spent time there. For example, B08-12 spent 31 days in the lease area before leaving and then re-entered for at least three more days (Table 2, Fig. 3).

Locations from five whales fell within the leased blocks of the lease area. The earliest date when a whale was located within the leased blocks was 16 October in 2006 and 13 September in 2008; one whale (B07-04) was located in the lease area in 2007, but it remained there for only three days, and none of its locations fell within a leased block. The duration of a whale's stay within the leased blocks ranged from less than one day to four days. These durations are negatively biased because they do not include the time within the leased blocks before the first and after the last recorded locations.

\section{Kernel Density Estimation}

We received 18458 locations from the 19 tagged whales. A total of 5369 locations were removed by filtering (Freitas et al., 2008), and an additional 785 locations were removed because they fell on land. After selecting the highest location class for each six-hour time period, we had a sample of 2932 locations for estimating kernel densities (Table 3). In total, 20 locations from four whales were collected in August. These locations were insufficient to estimate a 


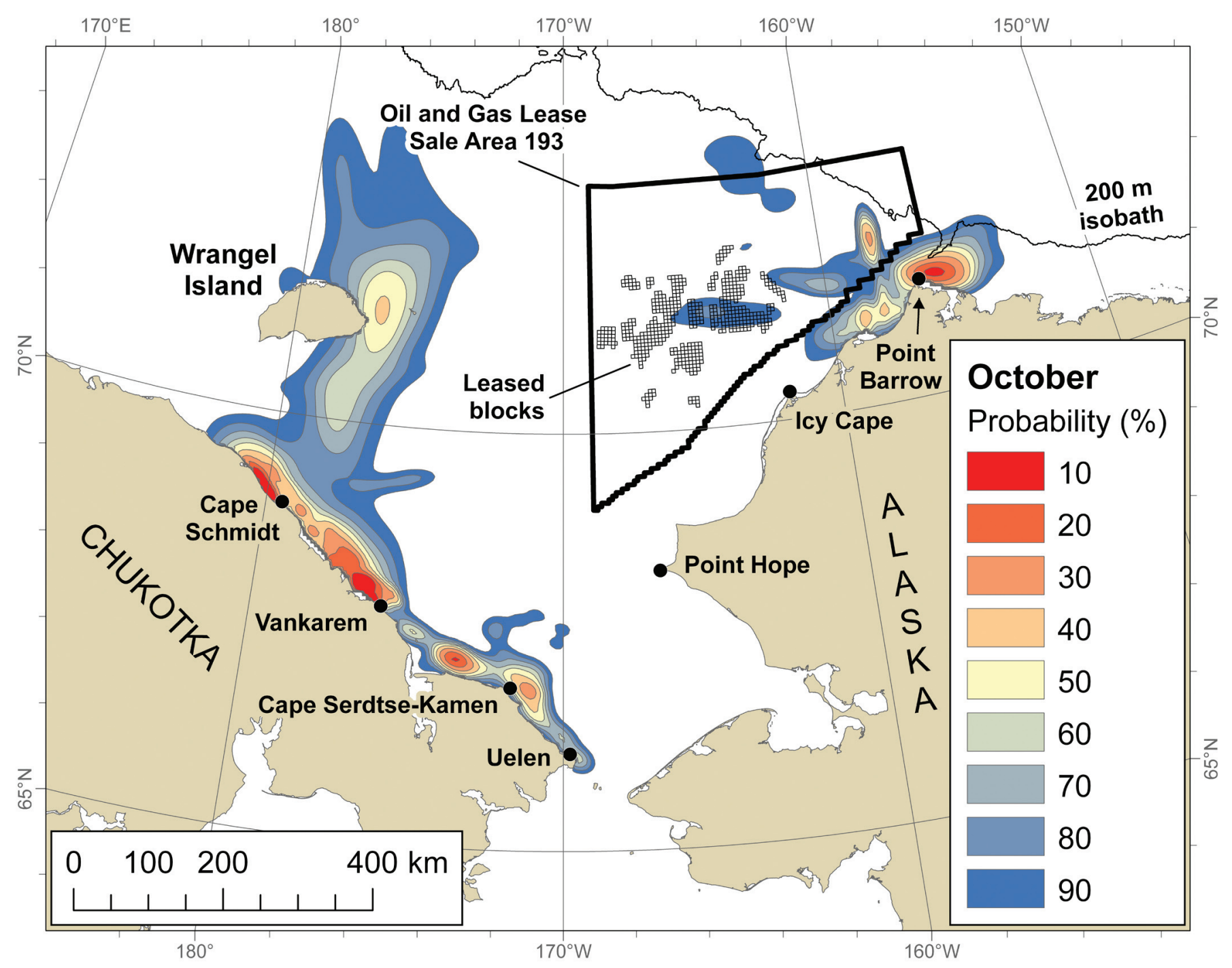

FIG. 5. Contours showing the probability of use (\%) by bowhead whales in October, 2006-08.

separate density for August, so we pooled them with locations from September. Some whales contributed only a few locations (less than 7), and these whales contributed little to the monthly kernel densities because we weighted the contribution of each whale by the number of its locations. For example, there were only three locations for whale B08-04 in September (Table 3), resulting in a weight of only 0.006 , which accounted for less than $1 \%$ of the kernel density for all whales in September.

In September, the highest probability of use was concentrated northeast of Point Barrow and extended to the east and west, south of the shelf break and the $200 \mathrm{~m}$ isobath (Fig. 4). Most whales were crossing the Chukchi Sea in September, en route to Wrangel Island and Chukotka. Because whales did not pause in the central Chukchi Sea, the migratory corridor is characterized by a low probability of use (Fig. 4). In October, probability of use was highest northeast of Point Barrow and along $\sim 600 \mathrm{~km}$ of the Chukotka coast (Fig. 5). An area centered east of Wrangel Island had a moderate probability of use. In November, the highest probability of use continued to be located along the Chukotka coast, but extended farther south than in October (Fig. 6). Probability of use was highest near Cape SerdtseKamen, but stretched from $\sim 75 \mathrm{~km}$ northeast of Vankarem to the Bering Strait. By December, use was most concentrated along the coast of Chukotka, from Cape SerdtseKamen to the Bering Strait (Fig. 7).

\section{Use of Lease Area and Leased Blocks}

There was a low density of bowhead whales within the lease area during September-December. The lease area was used most in September, when the area contained 31\% of the total probability of use for all whales. However, areas with the highest probability of use were located in the northeastern section of the lease area, not where the leased blocks were located. Leased blocks contained only $2 \%$ of the total probability of use (Fig. 4) by bowhead whales. In October, the entire lease area contained $7 \%$ of the total probability of use for all whales (Fig. 5), with only $1 \%$ of the probability of 


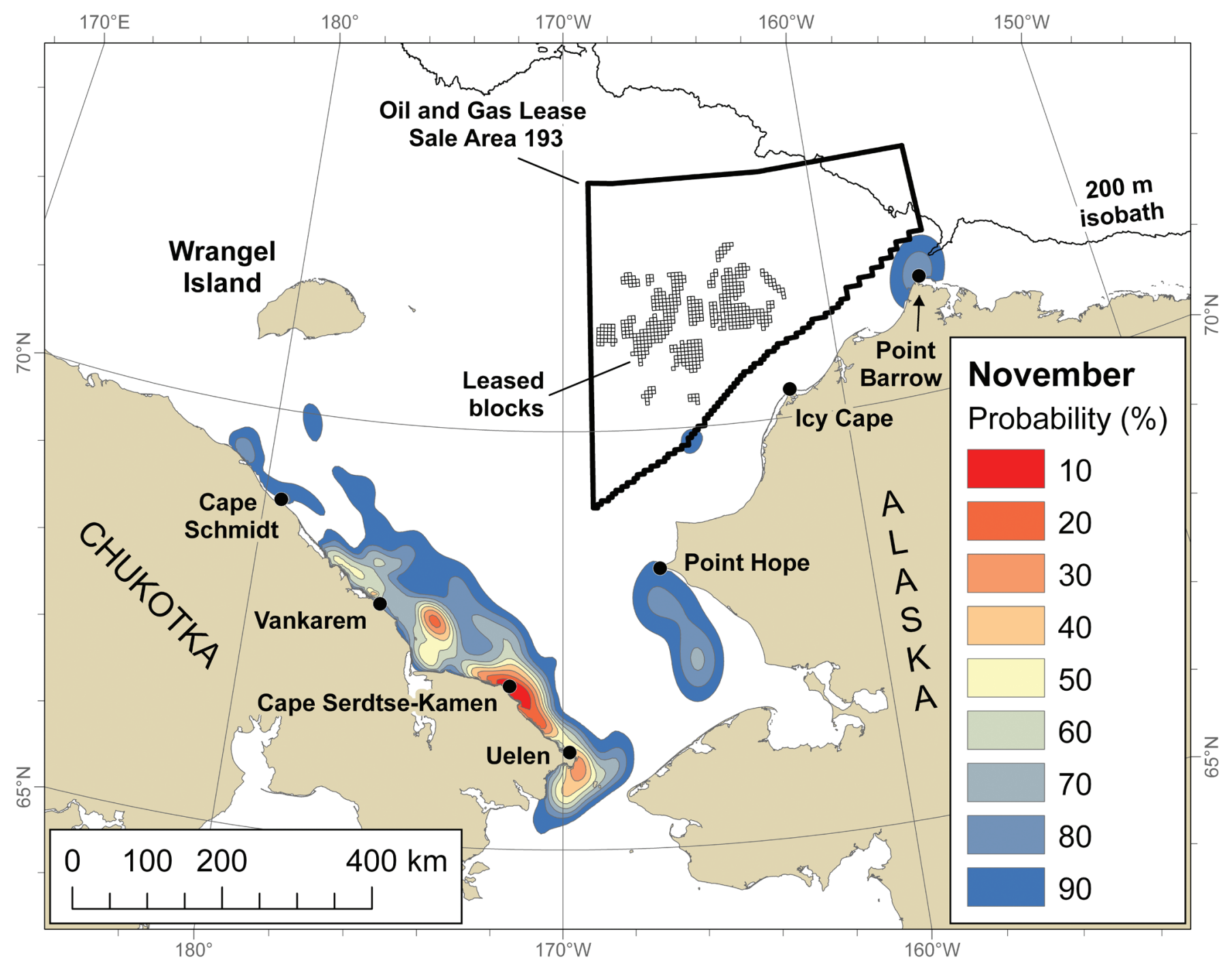

FIG. 6. Contours showing the probability of use (\%) by bowhead whales in November, 2006-08.

use contained within the leased blocks. In November, most of the whales were located along the coast of Chukotka; the lease area contained only $2 \%$ of the total probability of use, and the leased blocks contained less than $1 \%$. In December, the probability of use within the lease area increased to $5 \%$. However, whales were located mostly south of the leased blocks, and again, the leased blocks contained less than $1 \%$ of the probability of use.

\section{DISCUSSION}

\section{Limitations of the Data}

Ideally, the behavior of the satellite-tagged bowhead whales would be representative of the population. However, our sample size was small $(\mathrm{n}=19)$ relative to the size of the population ( 10470 ; George et al., 2004); 17 of 19 whales were tagged at the same location and time of year (i.e., near Point Barrow in September); and although the sex ratio was
2:1 ( 8 males and 4 females) for the whales in which gender was determined, 15 of the 19 tagged whales were immature $(<13 \mathrm{~m})$. Tagging a representative sample of sizes (i.e., ages) is important, because the Western Arctic population of bowhead whales migrates in pulses of similar-sized whales (Nerini et al., 1987; Huntington and Quakenbush, 2009a, b), and size has been determined to be an important factor in the timing of bowhead whale movements (Koski and Miller, 2009). Whalers from St. Lawrence Island have observed large whales arriving first at St. Lawrence Island in December and smaller ones arriving later (Noongwook et al., 2007). The whales we tagged were small (range = 9.1-14.5 m; Table 1), and we know from harvest dates that some whales reached St. Lawrence Island one to two weeks before the tagged whales did in 2008 .

More than half of the whales (11 of 19; Table 1) were tagged at one location (Point Barrow) during a five-day period in late September, and thus we likely missed earlier and later migrating groups. Future tagging should therefore include immature and mature whales of both sexes, tagged 


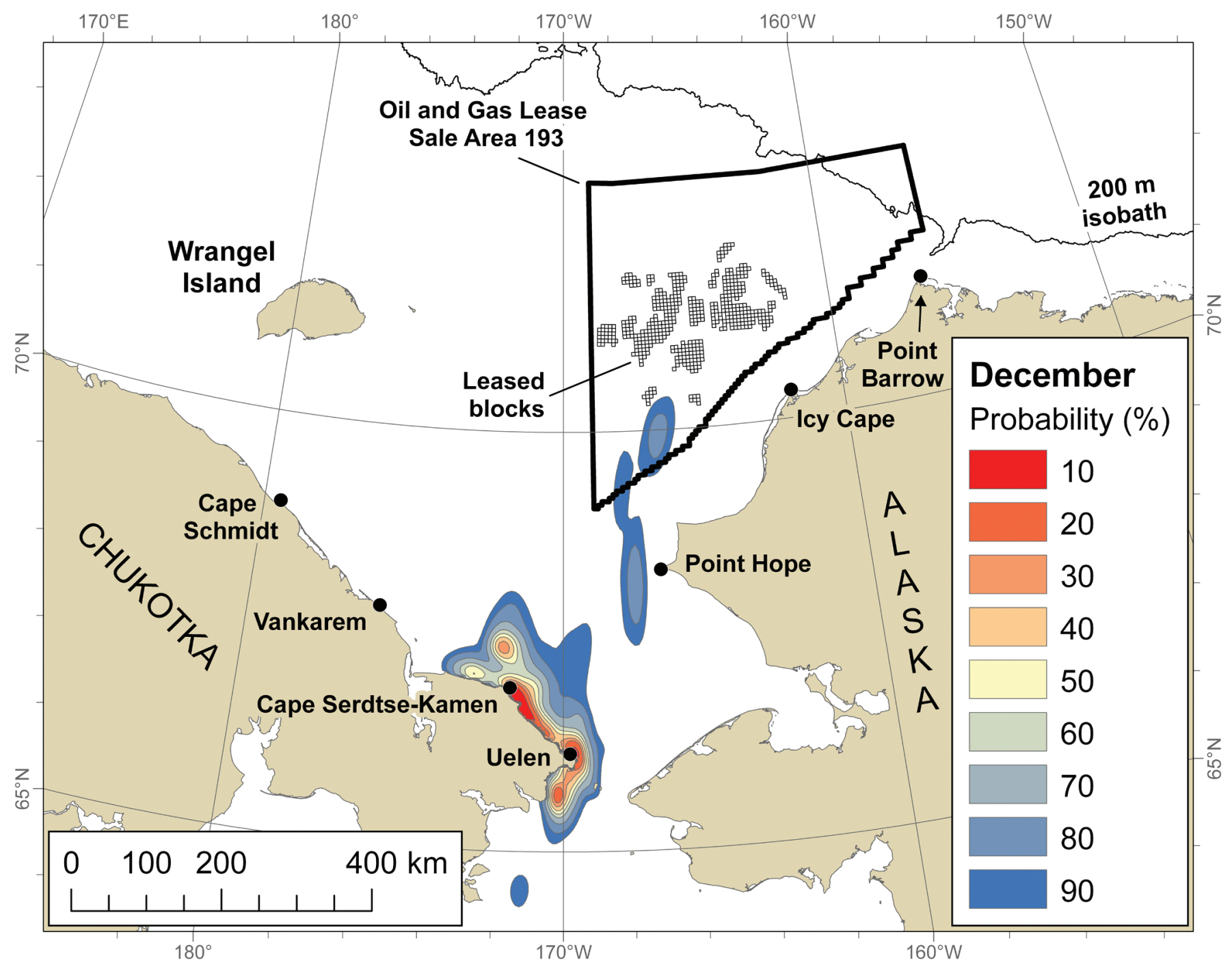

FIG. 7. Contours showing the probability of use (\%) by bowhead whales in December, 2006-08.

at different locations and at different times, to reduce potential bias in inferences on movements, use areas, and the timing of migration. However, even if a representative sample of the population is tagged, the timing and location of whale migration may be subject to variability in zooplankton productivity or concentration, sea ice, weather, and currents. Because sea ice has declined in parts of the Chukchi Sea (Moore and Laidre, 2006), the behavior we observed between 2006 and 2008 may differ from past behavior. For example, tagged whales remained in the Chukchi Sea through the month of December in 2008, possibly because of lighter sea ice coverage in recent years.

\section{Migration Paths}

Tracks of satellite-tagged bowhead whales in the Chukchi Sea from September to December showed that the general fall movement was from Point Barrow to the west or northwest. At least seven whales traveled to an area east or north of Wrangel Island and then moved southwest to the northern Chukotka coast (Fig. 2). Subsequently, all but one whale traveled slowly southeastward along the northern Chukotka coast, typically within $100 \mathrm{~km}$ of shore. Three whales that returned to Point Barrow also traveled initially in a westerly (B08-01 and B08-12) or northwesterly (B08-10) direction; however, upon their second departure from Point Barrow, two traveled west-southwest (B08-01 and B08-12) and one traveled southwest (B08-10). For four whales, the direction of migration could not be determined (Table 1).

Kernel densities showed that areas with the highest probability of use were near Point Barrow and the northeast Chukotka coast; the area along the east coast of Wrangel Island also had a moderate probability of use. The only whale that did not travel southeast along the Chukotka coast traveled southwest on the Alaska side of the Chukchi Sea (B08-10, Fig. 1); this whale was one of seven tagged whales estimated to be $\sim 10.0 \mathrm{~m}$ in length, and it was not different from other tagged whales in this size class from what we could determine. In 2008, shore-based observers near 
Uelen, Chukotka, began seeing bowhead whales in midNovember (Zdor, 2008). These observations corresponded with the increase in probability of use by the tagged whales near Uelen between October and November (compare Figs. 5 and 6 ).

Two of the three whales that returned to Point Barrow after entering the Chukchi Sea traveled northeast along the Alaska coast near Icy Cape (Fig. 3); the third whale passed near Icy Cape on its way southwest after leaving Point Barrow. Whales observed near Icy Cape in past summers were thought to be migrating south near the Alaska coast (Ljungblad et al., 1986; Moore, 1992), yet movements of tagged whales indicate some may be returning northeast to Point Barrow before later migrating west across the Chukchi Sea.

Nine of 12 tagged bowhead whales crossed the Chukchi Sea between Point Barrow and Wrangel Island or the Chukotka coast in 6-9 days (average $=7.1$ days). One whale paused for five days and took a total of 14 days to cross. Another (B08-01) crossed twice, taking seven days for the first northwest crossing and 14 days for the second, southwest route. One whale (B08-12) did not cross the Chukchi Sea and instead migrated down the Alaskan coast and reached the Chukotka coast near the Bering Strait 64 days after leaving Point Barrow. Travel time slowed considerably and movements were less direct once whales reached Chukotka. Whales spent an average of 59 days along the coast of Chukotka before entering the Bering Sea (range $=23-90 \mathrm{~d}$ ). Whales leaving Point Barrow later in the season tended to bypass Wrangel Island and travel directly to the Chukotka coast. For example, the three whales that migrated west from Point Barrow and subsequently returned there left Point Barrow for the second time between 13 October and 6 November and did not migrate back to Wrangel Island (Fig. 3). In contrast, all other whales but one left Point Barrow by 25 September (average $=22$ September; range $=$ 1 September-14 October), and all of these whales migrated past Wrangel Island.

\section{Identified Areas of Importance}

We used kernel densities to identify areas where bowhead whales spent more time; those areas were located near Barrow, east of Wrangel Island, and along the Chukotka coast. We suspect that areas characterized as having a high probability of use are important to bowhead whales for feeding. Concentrations of zooplankton are likely necessary for bowheads and other large baleen whales to feed efficiently in order to meet their energy requirements (Kenney et al., 1986; Lowry, 1993). Euphausiids are not thought to be produced in the Chukchi Sea but are advected from the Bering Sea (Siegel, 2000). Because euphausiids and other zooplankton are carried on currents, they can be concentrated by physical factors such as wind, bathymetry, and upwelling, and by oceanographic factors such as temperature and salinity (Berline et al., 2008). Feeding areas may have the physical and oceanographic factors necessary to concentrate prey each year; however, the variability in some of these factors may cause timing of prey concentration within years to be sporadic. Stomach contents of bowhead whales harvested there indicate that Point Barrow is a fall feeding area (Lowry and Frost, 1984; Lowry et al., 2004), and euphausiids (mostly Thysanoessa raschii) are the most common prey item (Lowry, 1993; Lowry et al., 2004). Physical and oceanographic factors near Point Barrow apparently concentrate zooplankton and develop favorable feeding conditions for bowhead whales intermittently from July through October. These factors include persistent winds from the east that push the Alaska Coastal Current offshore from Barrow Canyon, bringing zooplankton onto the shelf from upwelling northeast of Point Barrow. If winds lessen or shift south or southwest, the Alaska Coastal Current returns, trapping and concentrating zooplankton northeast of Point Barrow on the Beaufort Sea shelf (Ashjian et al., 2010).

Physical and oceanographic factors may concentrate zooplankton along the Chukotka coast just as they do near Point Barrow. There is independent evidence that Chukotka coastal areas are also important for feeding. Bowhead whales have been observed in many years along the northern coast of Chukotka from mid September to mid October (Johnson et al., 1981; Marquette et al., 1982; Melnikov and Bobkov, 1993; Moore et al., 1995; Ainana et al., 1997; Melnikov et al., 1997; Bogoslovskaya, 2003). Moore et al. (1995) encountered a large number of bowhead whales feeding between Cape Schmidt and Vankarem in October of 1992 and 1993. In 1993, a net tow for plankton found abundant euphausiids (T. raschii) associated with a sharp salinity gradient where bowhead whales appeared to be feeding.

Although little is known about the currents and conditions of the area near Wrangel Island, telemetry studies of beluga whales (Richard et al., 2001) and ringed seals (see beaufortseals.com/telemetry.htm) indicate these two species also spend more time in this area relative to other areas in the Chukchi Sea in the fall. Since beluga whales and ringed seals presumably spend their time there in order to forage, this area may also have the physical and oceanographic factors necessary to concentrate zooplankton that result in concentrations of fish and other invertebrate prey.

However, like Point Barrow, feeding areas with dense concentrations of high-quality zooplankton likely persist for relatively short periods of time because of changing physical and oceanographic conditions. Thus, whale movements within seasons may, in part, be a response to dynamic local foraging conditions. For example, when conditions are unfavorable for concentrating prey near Point Barrow, they may be favorable near Wrangel Island or the Chukotka coast.

Knowing where good feeding areas were in the past, and actively sampling prey in the present, may be how bowhead whales find feeding areas. Bowhead whales are extremely long-lived (> 100 yrs; George et al., 1999; George and Bockstoce, 2008) and could remember where good feeding areas were located in the past; hence, experience probably plays a role in deciding where to search for prey at certain times of year. Kenney et al. (2001) hypothesized that Atlantic right 
whales return to feeding areas based on experience, implying that learning is important. Yet, the results of real-time foraging most likely influence the areas bowhead whales select; the whales probably do not remain in areas where zooplankton is scarce.

Although our data on whale behavior may fit this hypothesis, we have no information on the availability of concentrated prey that we can correlate directly with tagged whale movements. Without data on prey concentration, we cannot say for sure what motivated the tagged whale movements, and we acknowledge that other factors, such as seismic surveys could explain the irregular movements of B08-12 (see Movements Relative to Disturbance below). However, we know of no industrial activities that may have affected two other whales that demonstrated similar behavior (B08-01 and B08-10).

Hence, on the basis of areas identified as important by our kernel density maps, substantial observations from the early 1970 s to the present, and oceanographic characteristics (i.e., features favoring advection and trapping of zooplankton), we suspect that the areas where tagged bowhead whales spent more time are important for feeding. Although areas of high probability of use are likely important to bowhead whales, areas of low probability of use may also be important. For example, kernel density maps are not useful for identifying migratory corridors. Kernel densities are based upon the number of satellite locations per whale per month. Because whales moved quickly between areas of concentrated use, migratory corridors contained few locations and therefore exhibited a low probability of use.

\section{Movements within the Lease Area}

All 19 tagged bowhead whales that were tracked leaving Point Barrow likely traveled through some portion of the lease area (Fig. 2). Fourteen bowhead whales transmitted enough locations to determine how they passed through the lease area, and five transmitted locations within the leased blocks, where oil exploration activity has occurred or is likely to occur. Generally, however, the probability that bowhead whales would use the lease area during the months examined was low (range: $2 \%$ to $31 \%$ ), with the highest probability of use in September. The temporal pattern was similar for the leased blocks, although the probability of use within those blocks ( $1 \%$ or less) was much lower than that for the lease area as a whole. Movements and behavior of tagged bowhead whales in this study indicated that the greatest potential for disturbance from industrial activities is near Point Barrow in September and October and in the lease area in September.

\section{Movements Relative to Sea Ice}

An important question is how the extent or thickness of sea ice may have affected the fall movements of bowhead whales in the Chukchi Sea. Ice maps from the Advanced Microwave Scanning Radiometer-EOS (AMSR-E) project at NASA (available from the National Snow and Ice Data Center, http://nsidc.org) show that the Chukchi Sea was virtually ice free until 1 November 2008. By 1 November, sea ice with $90 \%$ or greater coverage had formed within $100 \mathrm{~km}$ west of Wrangel Island and within $100 \mathrm{~km}$ north of Point Barrow. By 15 November, sea ice with $90 \%$ or greater coverage had formed at Point Barrow, encompassed Wrangel Island, and formed along the coast of Chukotka as far south as Cape Serdtse-Kamen (Fig. 8). However, the central Chukchi Sea was still ice free, and sea ice did not extend far from the Alaska coast. By 1 December, the entire Chukchi Sea was covered by sea ice with a concentration of $90 \%$ or greater.

Although bowhead whales generally preceded the progression of sea ice as they migrated from the Chukchi Sea into the Bering Sea, there is no evidence that sea ice conditions dictated their fall movements. With their perched blowholes, bowhead whales do not need much open water to breathe, and they have been known to break through at least $18 \mathrm{~cm}$ of sea ice (George et al., 1989). Visual inspection of MODIS ice images (available from NASA at: modis. gsfc.nasa.gov) suggested that the sea ice in the Chukchi Sea was highly fractured during our study period. George et al. (1989) also observed that during their spring migration, whales did not avoid sea ice that was thicker and more extensive than the ice that was present in fall during this study. However, the presence of sea ice may lessen the effects of wind on ocean currents that affect upwelling, which may alter the way in which krill concentrate and therefore the quality of forage in a given area (Moore and Laidre, 2006). Sea ice does not seem to directly control the movement of bowhead whales, except that whales avoid areas of continuous shorefast ice; however, sea ice does limit light penetration and wind-driven upwelling, and thus controls whale movements by influencing prey availability.

\section{Movements Relative to Disturbance}

Human disturbance from seismic activities or shipping could have affected the movements of bowhead whales during the study period. In 2006, a 2-D seismic survey occurred within the northeast portion of the lease area between 13 October and 11 November (Funk et al., 2007). Whale B06-01 passed through the seismic survey area sometime between 15 and 19 October while migrating between Barrow and Chukotka. We do not know where the seismic ship was located when B06-01 passed by and cannot comment on how seismic activity may have affected movements of this whale. In 2007, a 3-D seismic survey was conducted within the leased blocks between 28 August and 10 September (Ireland et al., 2009). During this survey, B07-04 migrated from Barrow to Chukotka, crossing the Chukchi Sea farther north than any other whale. Satellite locations indicated B07-04 was never closer than $\sim 175 \mathrm{~km}$ to seismic activity; whether seismic activity altered the whale's migratory route is unknown. In 2008, a lower-energy seismic survey (used to detect possible hazards to drilling that are on 


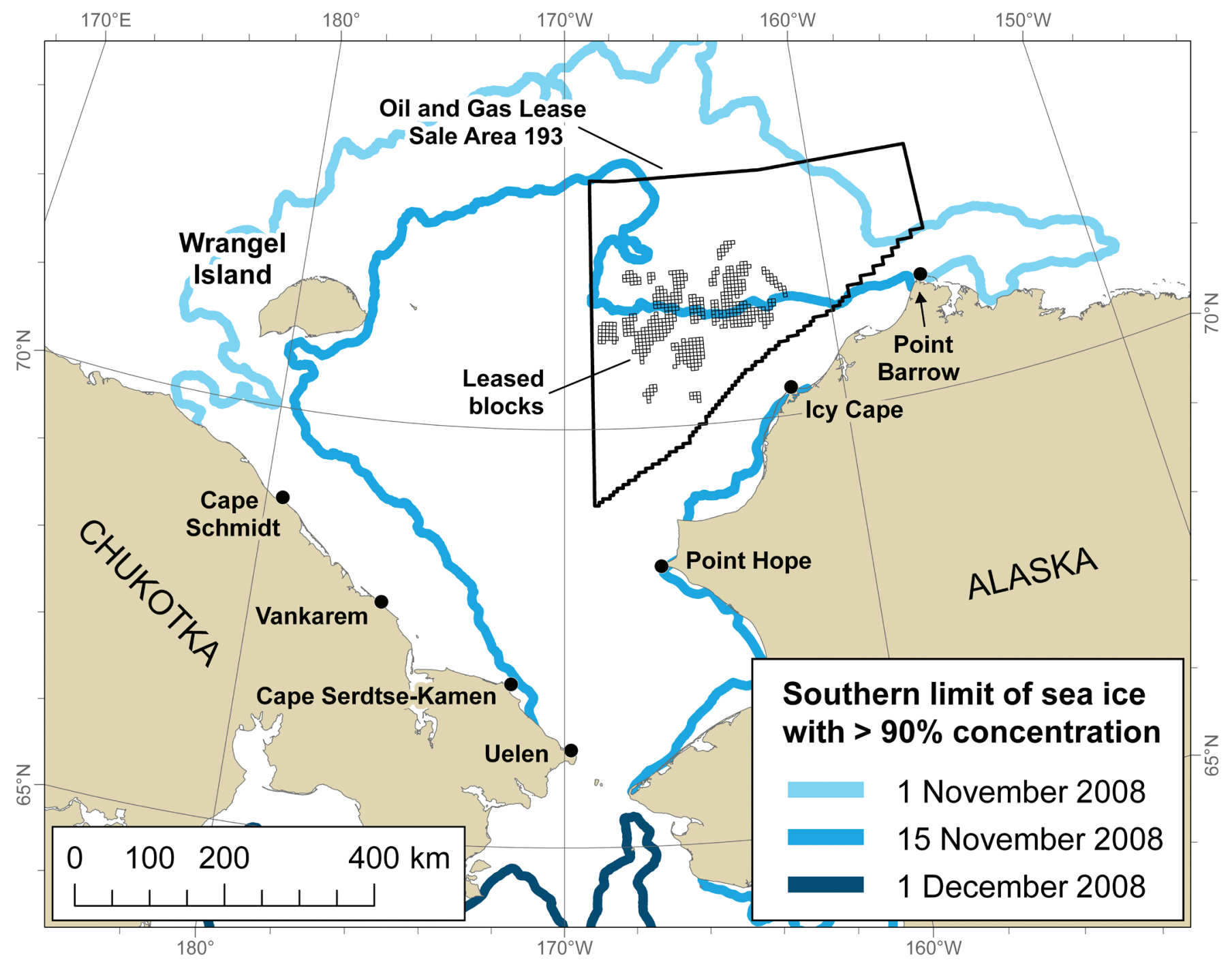

FIG. 8. Southern extent of sea ice with $90 \%$ or greater concentration in the Chukchi Sea.

or just below the bottom) was conducted in the Chukchi Sea between 7 September and 31 October. This survey occurred within a $2000 \mathrm{~km}^{2}$ area surrounding the Klondike Prospect, $\sim 125 \mathrm{~km}$ northwest of Icy Cape, in the southern portion of the lease area (Brueggeman, 2009). Shallow hazard surveys use less energy and produce less noise than the 2-D or 3-D seismic arrays used for deep surveys. Although no bowhead whales were observed within this survey area, B08-12 was moving west on 27 September after leaving Point Barrow two days earlier and was no more than $\sim 90 \mathrm{~km}$ away from the survey area when it reversed direction and returned to Point Barrow (Fig. 3). Although the level of noise produced during shallow hazard surveys would be less likely to affect the movements of a whale $\sim 90 \mathrm{~km}$ away than 2-D and 3-D seismic operations, it is possible that whale B08-12 turned around as a result of seismic activity. The majority of whale movements we documented were outside of the areas and time periods of any seismic activity. However, even when whales are near survey areas, assessing whether whale movements are affected by seismic activity will require a cooperative approach. The precise locations of seismic ships conducting surveys are often proprietary knowledge to prevent one company from knowing the specific lease blocks another company is interested in.

\section{Future Disturbance and Mitigation Measures}

We calculated the spatial and temporal probability of use of the Chukchi Sea by satellite-tagged bowhead whales and identified specific areas and times of possible interaction between industrial activities and bowhead whales. With this information, preliminary strategies could be developed for mitigating the effects of oil and gas activities and shipping on whales in the Chukchi Sea. Measures that would minimize disturbance include adjusting the timing of oil and gas activities and the location of shipping lanes to avoid concentrations of bowhead whales.

Drilling is currently planned to begin within the lease area in 2010 (MMS, 2009). In addition to the blocks currently leased, two more sales are scheduled for the lease 
area (i.e., Chukchi Sea Sales 212 in 2010 and 221 in 2012; MMS Alaska Lease Sales Schedule available online at http://www.mms.gov/LD/AKsales.htm) that may result in more leased blocks, 3-D seismic exploration, and development activity. Although most industry activity is currently on the Alaska side of the Chukchi Sea, high potential for oil on the Russian side, in the North and South Chukchi basins, has also produced keen interest from industry, and seismic surveys were conducted there in 2006 (available online from http://www.geo365.no/thearctic/russian_ch/). The North Chukchi Basin includes the area northeast of Wrangel Island, where the northernmost bowhead whale tracks crossed the Chukchi Sea. The South Chukchi Basin includes the area offshore of the northern Chukotka coast, where the tagged whales that bypassed Wrangel Island crossed the Chukchi Sea. Therefore, oil and gas activity could increase in areas where concentrated use by bowhead whales has been documented.

Shipping is expected to increase as the ice-free season lengthens (ACIA, 2004; Treadwell, 2008) and will likely result in more noise and ship strikes. For example, the North Atlantic right whale (Eubalaena glacialis), a close relative to bowhead whales, migrates and feeds along the east coast of the United States within busy commercial shipping lanes. Ship collisions and propeller wounds are a significant source of mortality for North Atlantic right whales in these areas (Moore et al., 2004). Similarly bowhead whales will likely be susceptible to ship-related injuries should vessel traffic increase in the areas they frequent. Areas of high importance for bowhead whales (i.e., Point Barrow and Chukotka) during September through December generally fell within $100 \mathrm{~km}$ of shore (Figs. 4-7). Therefore, shipping traffic within $100 \mathrm{~km}$ from shore at Point Barrow or Chukotka during this time period could cause significant disturbance. Ships traveling through the narrow area west of Little Diomede Island in November and December would also have high potential for encountering bowhead whales.

We expect the potential for human-whale conflicts to increase because the Western Arctic bowhead whale population is increasing (George et al., 2004; Zeh and Punt, 2005) and sea ice is decreasing. Decreasing sea ice will likely lead to more industrial activity, such as petroleum exploration and extraction and shipping. Developing mitigation measures to minimize the impact of industrial activity on bowhead whales is therefore both important and urgent. We have identified areas within the Chukchi Sea that are likely important for a large proportion of the bowhead whale population. Although a larger and perhaps more representative sample of whale movements may lead to some modification of areas of importance, we now have enough information regarding the location and timing of bowhead use to identify zones of potential conflict between bowhead whales and industrial activity.

\section{ACKNOWLEDGEMENTS}

This cooperative project involved contributions and hard work from many organizations, agencies, and individuals, including the following: the Alaska Eskimo Whaling Commission (the late Arnold Brower, Sr., Harry Brower, Jr., and Ray Koonook), the North Slope Borough (Billy Adams, Robert Suydam, and Ambrose Leavitt), the Barrow and Kaktovik Whaling Captains' Associations (Eugene Brower, Fenton Rexford, Joe Kaleak, George Tagarook, and Eddie Arey), the Barrow Arctic Science Consortium (Lewis Brower), the Aklavik and Tuktoyaktuk Hunters and Trappers' Committees (Angus Alunik, Dennis Arey, Larry Arey, Pat Kasook, Buddy Gruben, Douglas Panaktalok, Charles Pokiak, and James Pokiak), and the Department of Fisheries and Oceans Canada (Lois Harwood, Kevin Bill, Tim Leblanc, Stephen Raverty, and Terry Stein). The Greenland Institute of Natural Resources provided Mikkel Villum Jensen, who designed and built the tag attachments and, along with Anders Villum Jensen, assisted with tagging in Alaska and Canada. The manuscript was reviewed and improved by comments from Randall Reeves, Sue Cosens, and an anonymous reviewer. Funding for this research was provided by the U.S. Minerals Management Service (Contract No. MMS 01-05-CT39268), with superior support and assistance from Charles Monnett. Operations in Canada were funded largely by the Department of Fisheries and Oceans, with critical assistance and support from Lois Harwood. Bowhead research has been conducted under a Marine Mammal Protection Act permit issued to National Marine Fisheries Service (No. 782-1719), Canadian License No. S-07/08-4007-IN, and the Alaska Department of Fish and Game Animal Care and Use permit No. 06-16.

\section{REFERENCES}

ACIA. 2004. Impacts of a warming Arctic: Arctic climate impact assessment. Cambridge: Cambridge University Press. www. acia.uaf.edu.

Ainana, L., Mymrin, N., Bogoslovskaya, L., and Veter O. 1997. Role of the Eskimo Society of Chukotka in encouraging traditional native use of wildlife resources by Chukotka natives and in conducting shore based observations in the study of migration patterns of the bowhead whale, Balaena mysticetus, in the waters of the Bering Sea and Chukchi Sea adjacent to the Chukotka Peninsula (Russia) during January to September, 1996. Report to North Slope Borough from Eskimo Society of Chukotka, Provideniya, Russia. Available from the Alaska Department of Fish and Game, 1300 College Road, Fairbanks, Alaska 99701. 122 p.

Argos. 2008. Argos user's manual. www.argos-system.org/ manual/.

Ashjian, C.J., Braund, S.R., Campbell, R.G., George, J.C., Kruse, J., Maslowski, W., Moore, S.E., et al. 2010. Climate variability, oceanography, bowhead whale distribution, and Iñupiat subsistence whaling near Barrow, Alaska. Arctic 63: $179-194$. 
Berline, L., Spitz, Y.H., Ashjian, C.J., Campbell, R.G., Maslowski, W., and Moore, S.E. 2008. Euphausiid transport in the Western Arctic Ocean. Marine Ecology Progress Series 360:163-178, doi:10.3354/meps07387.

Bogoslovskaya, L. 2003. The bowhead whale off Chukotka: Integration of scientific and traditional knowledge. In: McCartney, A.P., ed. Indigenous ways to the present: Native whaling in the Western Arctic. Studies in Whaling 6. Edmonton: Canadian Circumpolar Institute Press, University of Alberta.

Bogoslovskaya, L.S., Votrogov, L.M., and Krupnik, I.I. 1982. The bowhead whale off Chukotka: Migrations and aboriginal whaling. Report of the International Whaling Commission 32:391-399.

Braham, H.W. 1995. Sex and size composition of bowhead whales landed by Alaskan Eskimo whalers. In: McCartney, A.P., ed. Hunting the largest animals, native whaling in the Western Arctic and Subarctic. Studies in Whaling 3, Occasional Publication 36. Edmonton: Canadian Circumpolar Institute, University of Alberta.

Braham, H.W., Fraker, M.A., and Krogman, B.D. 1980. Spring migration of the Western Arctic population of bowhead whales. Marine Fisheries Review 42(9):36-46.

Brodie, P.F. 1980. A preliminary investigation of the energetics of the bowhead whale (Balaena mysticetus). Report of the International Whaling Commission 31:501-502.

Brueggeman, J.J. 1982. Early spring distribution of bowhead whales in the Bering Sea. Journal of Wildlife Management 46:1036-1044.

- 2009. 90-day report of the Marine Mammal Monitoring Program for the ConocoPhillips Alaska Shallow Hazards Survey Operations during the 2008 open water season in the Chukchi Sea. Prepared for ConocoPhillips Alaska, Inc. nmfs. noaa.gov/pr/permits/incidental.htm. 49 p.

Carroll, G.M., and Smithhisler, J.R. 1980. Observations of bowhead whales during spring migrations. Marine Fisheries Review 42(9-10):80-85.

Duong, T. 2007. ks: Kernel density estimation and kernel discriminant analysis for multivariate data in R. Journal of Statistical Software 21:1-16.

Duong, T., and Hazelton, M.L. 2005. Cross-validation bandwidth matrices for multivariate kernel density estimation. Scandinavian Journal of Statistics 32:485-506.

Durham, F.E. 1979. The catch of bowhead whales (Balaena mysticetus) by Eskimos, with emphasis on the Western Arctic. Contributions in Science. Natural History Museum of Los Angeles County 314:1-14.

Fraker, M.A., and Bockstoce, J.R. 1980. Summer distribution of bowhead whales in the eastern Beaufort Sea. Marine Fisheries Review 42(9-10):57-64.

Freitas, C., Lydersen, C., Fedak, M.A., and Kovacs, K.M. 2008. A simple new algorithm to filter marine mammal Argos locations. Marine Mammal Science 24:315-325.

Funk, D.W., Rodrigues, R., Ireland, D.S., and Koski, W.R., eds. 2007. Joint monitoring program in the Chukchi and Beaufort seas, July-November 2006. LGL Report P891-2. www.nmfs. noaa.gov/pr/pdfs/permits/jmp_report.pdf.
George, J.C., and Bockstoce, J.R. 2008. Two historical weapon fragments as an aid to estimating the longevity and movements of bowhead whales. Polar Biology 31(6):751-754.

George, J.C., Clark, C., Carroll, G.M., and Ellison, W.T. 1989. Observations on the ice-breaking and ice navigation behavior of migrating bowhead whales (Balaena mysticetus) near Point Barrow, Alaska, spring 1985. Arctic 42:24-30.

George, J.C., Bada, J., Zeh, J., Scott, L., Brown, S.E., O’Hara, T., and Suydam, R. 1999. Age and growth estimates of bowhead whales (Balaena mysticetus) via aspartic acid. Canadian Journal of Zoology 77:571 - 580.

George, J.C., Zeh, J., Suydam, R., and Clark, C. 2004. Abundance and population trend (1978-2001) of Western Arctic bowhead whales surveyed near Barrow, Alaska. Marine Mammal Science 20:755-773.

Gitzen, R.A., and Millspaugh, J.J. 2003. Comparison of leastsquares cross-validation bandwidth options for kernel homerange estimation. Wildlife Society Bulletin 31:823-831.

Heide-Jørgensen, M.P., Kleivane, L., Øien, N., Laidre, K.L., and Jensen, M.V. 2001. A new technique for deploying satellite transmitters on baleen whales: Tracking a blue whale (Balaenoptera musculus) in the North Atlantic. Marine Mammal Science 17:949-954.

Heide-Jørgensen, M.P., Laidre, K.L., Wiig, Ø., Jensen, M.V., Dueck, L., Maiers, L.D., Schmidt, H.C., and Hobbs, R.C. 2003. From Greenland to Canada in ten days: Tracks of bowhead whales, Balaena mysticetus, across Baffin Bay. Arctic 56: $21-31$.

Huntington, H.P., and Quakenbush, L.T. 2009a. Traditional knowledge of bowhead whale migratory patterns near Kaktovik and Barrow, Alaska. Report to the Alaska Eskimo Whaling Commission. 12 p. Available from the Alaska Department of Fish and Game, 1300 College Road, Fairbanks, Alaska 99701.

- 2009b. Traditional knowledge of bowhead whale migratory patterns near Wainwright, Alaska. Report to the Alaska Eskimo Whaling Commission. 9 p. Available from the Alaska Department of Fish and Game, 1300 College Road, Fairbanks, Alaska 99701.

Ireland, D.S., Funk, D.W., Rodrigues, R., and Koski, W.R., eds. 2009. Joint monitoring program in the Chukchi and Beaufort seas, open water seasons, 2006-2007. LGL Report P971-2. www.nmfs.noaa.gov/pr/pdfs/permits/arctic_seismic_report. pdf.

Johnson, J.H., Braham, H.W., Krogman, B.D., Marquette, W.M., Sonntag, R.M., and Rugh, D.J. 1981. Research conducted on bowhead whales, June 1979 to June 1980. Report of the International Whaling Commission 31:461-475.

Keating, K.A. 1994. An alternative index of satellite telemetry location error. Journal of Wildlife Management 58:414-421.

Kenney, R.D., Hyman, M.A.M., Owen, R.E., Scott, G.P., and Winn, H.E. 1986. Estimation of prey densities required by western North Atlantic right whales. Marine Mammal Science 2:1 - 13, doi:10.1111/j.1748-7692.1986.tb00024.x.

Kenney, R.D., Mayo, C.A., and Winn, H.E. 2001. Migration and foraging strategies at varying spatial scales in western North Atlantic right whales: A review of hypotheses. Journal of Cetacean Research Management (Special Issue) 2:251-260. 
Kernohan, B.J., Gitzen, R.A., and Millspaugh, J.J. 2002. Analysis of animal space use and movements. In: Millspaugh, J.J., and Marzluff, J.M., eds. Radio tracking and animal populations. San Diego, California: Academic Press. 125-166.

Koski, W.R., and Miller, G.W. 2009. Habitat use by different size classes of bowhead whales in the central Beaufort Sea during late summer and autumn. Arctic 62:137-150.

LaBelle, J.C., Wise, J.L., Voelker, R.P., Schulze, R.H., and Wohl, G.M. 1983. Alaska marine ice atlas. Arctic Environmental Information and Data Center, University of Alaska.

Ljungblad, D.K., Moore, S.E., and Van Schoik, D.R. 1986. Seasonal patterns of distribution, abundance, migration and behavior of the Western Arctic stock of bowhead whales, Balaena mysticetus in Alaskan seas. Report of the International Whaling Commission (Special Issue 8):177-205.

Ljungblad, D.K., Moore, S.E., Clarke, J.T., and Bennett, J.C. 1987. Distribution, abundance, behavior and bioacoustics of endangered whales in the Alaskan Beaufort and eastern Chukchi seas, 1979-86. Report from the Naval Ocean Systems Center to U.S. Minerals Management Service. NTIS No. ADA183934/9. Available from Alaska Department of Fish and Game, 1300 College Road, Fairbanks, Alaska 99701. 391 p.

Lowry, L.F. 1993. Foods and feeding ecology. In: Burns, J.J., Montague, J.J., and Cowles, C.J., eds. The bowhead whale. Society for Marine Mammalogy, Special Publication No. 2. Lawrence, Kansas: Allen Press. 201-238.

Lowry, L.F., and Frost, K.J. 1984. Foods and feeding of bowhead whales in western and northern Alaska. Scientific Reports of the Whale Research Institute, Tokyo 35:1-16.

Lowry, L.F., Sheffield, G., and George, J.C. 2004. Bowhead whale feeding in the Alaskan Beaufort Sea, based on stomach contents analysis. Journal of Cetacean Research Management 6(3):215-223.

Marquette, W.M. 1978. The 1976 catch of bowhead whales, Balaena mysticetus, by Alaskan Eskimos. Marine Fisheries Review 40(11):18-27.

Marquette, W.M., Braham, H.W., Nerini, M.K., and Miller, R.V. 1982. Bowhead whale studies, autumn 1980-spring 1981: Harvest, biology, and distribution. Report of the International Whaling Commission 32:357-370.

Mate, B.R., Krutzikowsky, G.K., and Winsor, M.H. 2000. Satellite-monitored movements of radio-tagged bowhead whales in the Beaufort and Chukchi seas during the latesummer feeding season and fall migration. Canadian Journal of Zoology 78:1168-1181.

Melnikov, V.V., and Bobkov, A.V. 1993. Bowhead whale migration in the Chuckchee Sea. Russian Journal of Marine Biology 19(3):180-185. Translated from Biologya Morya 3:60-67.

Melnikov, V.V., Zelensky, M.A., and Bychkov, V.V. 1997. Seasonal migrations and distribution of bowhead whale in waters of Chukotka. Russian Journal of Marine Biology 23(4):175 - 183. Translated from Russian by Biologya Morya 1997.

Melnikov, V.V., Litovka, D.I., Zagrebin, I.A., Zelensky, G.M., and Ainana, L.I. 2004. Shore-based counts of bowhead whales along the Chukotka Peninsula in May and June 1999-2001. Arctic 57:290-298.
Miller, R.V., Rugh, D.J., and Johnson, J.H. 1986. The distribution of bowhead whales, Balaena mysticetus, in the Chukchi Sea. Marine Mammal Science 2:214-222.

MMS (Minerals Management Service). 2009. Environmental Assessment, Shell Gulf of Mexico, Inc., 2010 Exploration Drilling Program, Burger Crackerjack, and SW Shoebill Prospects, Chukchi Sea Outer Continental Shelf, Alaska. OCS EIS/EA MMS 2009-061. http://www.mms.gov/Alaska/ref/ EIS\%20EA/2009_Chukchi_2010EA/EA_2010EP.htm.

Monnett, C., and Treacy, S.D. 2005. Aerial surveys of endangered whales in the Beaufort Sea, Fall 2002-2004. OCS Study, MMS 2005-037. Report to U.S. Minerals Management Service, Alaska OCS Region, Anchorage. Available from Minerals Management Service, 3801 Centerpoint Drive, Suite 500, Anchorage, Alaska 99503. 151 p.

Moore, M.J., Knowlton, A.R., Kraus, S.D., McLellan, W.A., and Bonde, R.K. 2004. Morphometry, gross morphology and available histopathology in North Atlantic right whale (Eubalaena glacialis) mortalities (1970-2002). Journal of Cetacean Research and Management 6(3):199-214.

Moore, S.E. 1992. Summer records of bowhead whales in the northeastern Chukchi Sea. Arctic 45:398-400.

- 2000. Variability of cetacean distribution and habitat selection in the Alaskan Arctic, autumn 1982-91. Arctic 53:448-460.

Moore, S.E., and Clarke, J.T. 1992. Distribution, abundance and behavior of endangered whales in the Alaskan Chukchi and western Beaufort seas, 1991: With a review 1982-91. Report from SAIC, Maritime Services Division to U.S. Minerals Management Service, Alaska OCS Region. Available from Minerals Management Service, 3801 Centerpoint Drive, Suite 500, Anchorage, Alaska 99503. 237 p.

Moore, S.E., and Laidre, K.L. 2006. Trends in sea ice cover within habitats used by bowhead whales in the western Arctic. Ecological Applications 16(3):932-944.

Moore, S.E., and Reeves, R.R. 1993. Distribution and movement. In: Burns, J.J., Montague, J.J., and Cowles, C.J., eds. The bowhead whale. Society for Marine Mammalogy, Special Publication No. 2. Lawrence, Kansas: Allen Press. 313-386.

Moore, S.E., George, J.C., Coyle, K.O., and Weingartner, T.J. 1995. Bowhead whales along the Chukotka coast in autumn. Arctic 48:155-160.

Moore, S.E., DeMaster, D.P., and Dayton, P.K. 2000. Cetacean habitat selection in the Alaskan Arctic during summer and autumn. Arctic 53:432-447.

Nerini, M.K., Withrow, D., and Strickland, K. 1987. Length structure of the bowhead whale population derived from aerial photogrammetry with notes on recruitment, spring 1985 and 1986. Paper SC/39/PS14 presented to the International Whaling Commission Scientific Committee. 22 p. Available from IWC, The Red House, 135 Station Road, Impington Cambridge, Cambridgeshire, CB49NP, United Kingdom.

Noongwook, G., the Native Village of Savoonga, the Native Village of Gambell, Huntington, H.P., and George, J.C. 2007. Traditional knowledge of the bowhead whale (Balaena mysticetus) around St. Lawrence Island, Alaska. Arctic 60: $47-54$. 
Park, B.U., and Marron, J.S. 1990. Comparison of data-driven bandwidth selectors. Journal of the American Statistical Association 85:65-78.

Richard, P.R., Martin, A.R., and Orr, J.R. 2001. Summer and autumn movements of belugas of the eastern Beaufort Sea stock. Arctic 54:223-236.

Richardson, W.J., Davis, R.A., Evans, C.R., and Norton, P. 1985. Distribution of bowheads and industrial activity, 1980-84. In: Richardson, W.J., ed. Behavior, disturbance responses and distribution of bowhead whales, Balaena mysticetus, in the eastern Beaufort Sea, 1980-84. Report from LGL Ltd. to U.S. Minerals Management Service. NTIS P87 124376/AS. Available from Alaska Department of Fish and Game, 1300 College Road, Fairbanks, Alaska 99701. 255-306.

Rugh, D.J., and Cubbage, J.C. 1980. Migration of bowhead whales past Cape Lisburne, Alaska. Marine Fisheries Review 42 (9-10):46-51.

Rugh, D., DeMaster, D., Rooney, A., Breiwick, J., Sheldon, K., and Moore, S. 2003. A review of bowhead whale (Balaena mysticetus) stock identity. Journal of Cetacean Research and Management 5(3):267-279.

Rugh, D.J., Koski, W.R., George, J.C., and Zeh, J.E. 2008. Interyear re-identification of bowhead whales during their spring migration past Point Barrow, Alaska, 1984-1994. Journal of Cetacean Research and Management 10(3):195-200.

Seaman, D.E., and Powell, R.A. 1996. An evaluation of the accuracy of kernel density estimators for home range analysis. Ecology 77:2075-2085.

Seaman, D.E., Millspaugh, J.J., Kernohan, B.J., Brundige, G.C., Raedeke, K.J., and Gitzen, R.A. 1999. Effects of sample size on kernel home range estimates. Journal of Wildlife Management 63:739-747.

Siegel, V. 2000. Krill (Euphausiacea) life history and aspects of population dynamics. Canadian Journal of Fisheries and Aquatic Sciences (Suppl. 3):130-150.

Silverman, B.W. 1986. Density estimation for statistics and data analysis. London: Chapman and Hall.

Stoker, S.W., and Krupnik, I.I. 1993. Subsistence whaling. In: Burns, J.J., Montague, J.J., and Cowles, C.J., eds. The bowhead whale. Society for Marine Mammalogy, Special Publication No. 2. Lawrence, Kansas: Allen Press. 579-629.

Stringer, W.J., and Groves, J.E. 1991. Location and areal extent of polynyas in the Bering and Chukchi seas. Arctic 44 (Suppl. 1):164-171.

Suydam, R.S., and George, J.C. 2004. Subsistence harvest of bowhead whales (Balaena mysticetus) by Alaskan Eskimos, 1974 to 2003. Paper SC/56/BRG 12 presented to the International
Whaling Commission Scientific Committee. Available from IWC, The Red House, 135 Station Road, Impington Cambridge, Cambridgeshire, CB49NP, United Kingdom.

Treacy, S.D. 1992. Aerial surveys of endangered whales in the Beaufort Sea, Fall 1991. OCS Study, MMS 92-0017. Report of U.S. Minerals Management Service, Alaska OCS Region, Anchorage. Available from Minerals Management Service, 3801 Centerpoint Drive, Suite 500, Anchorage, Alaska 99503. $67 \mathrm{p}$.

- 2002. Aerial surveys of endangered whales in the Beaufort Sea, Fall 2001. OCS Study, MMS 2002-061. Report of U.S. Minerals Management Service, Alaska OCS Region, Anchorage. Available from Minerals Management Service, 3801 Centerpoint Drive, Suite 500, Anchorage, Alaska 99503. $117 \mathrm{p}$.

Treadwell, M. 2008. Is America prepared for an accessible Arctic? Senate Commerce Committee Hearing "Climate Change Impacts on the Transportation Sector," 24 June 2008, Washington, D.C. www.arctic.gov/testimony/treadwell-06-2408.pdf.

Vincent, C., McConnell, B.J., Ridoux, V., and Fedak, M.A. 2002. Assessment of Argos location accuracy from satellite tags deployed on captive gray seals. Marine Mammal Science 18:156- 166 .

Wand, M., and Jones, M. 1995. Kernel smoothing. London: Chapman and Hall.

Wartzok, D., Watkins, W.A., Würsig, B., Guerrero, J., and Schoenherr, J. 1990. Movements and behaviors of bowhead whales. Report to Amoco Production Company. Available from Alaska Department of Fish and Game, 1300 College Road, Fairbanks, Alaska 99701. 197 p.

Worton, B.J. 1989. Kernel methods for estimating the utilization distribution in home-range studies. Ecology 70:164-168.

Zdor, E. 2008. The Association of Traditional Marine Mammal Hunters of Chukotka. Report to North Slope Borough. Available from Alaska Department of Fish and Game, 1300 College Road, Fairbanks, Alaska 99701. 2 p.

Zeh, J.E., and Punt, A.E. 2005. Updated 1978-2001 abundance estimates and their correlations for the Bering-ChukchiBeaufort seas stock of bowhead whales. Journal of Cetacean Research and Management 7(2):169-175.

Zeh, J.E., Clark, C.W., George, J.C., Withrow, D., Carroll, G.M., and Koski, W.R. 1993. Current population size and dynamics. In: Burns, J.J., Montague, J.J., and Cowles, C.J., eds. The bowhead whale. Society for Marine Mammalogy, Special Publication No. 2. Lawrence, Kansas: Allen Press. 409-489. 